Edith Cowan University

Research Online

2012

\title{
An exploratory investigation into knowledge management in Western Australian knowledge-intensive small businesses
}

Shukrullah Fassehi

Edith Cowan University

Follow this and additional works at: https://ro.ecu.edu.au/theses_hons

Part of the Entrepreneurial and Small Business Operations Commons

\section{Recommended Citation}

Fassehi, S. (2012). An exploratory investigation into knowledge management in Western Australian knowledge-intensive small businesses. https://ro.ecu.edu.au/theses_hons/42

This Thesis is posted at Research Online.

https://ro.ecu.edu.au/theses_hons/42 
Edith Cowan University

Research Online

2012

\section{An exploratory investigation into knowledge management in Western Australian knowledge- intensive small businesses}

Shukrullah Fassehi

Edith Cowan University

\section{Recommended Citation}

Fassehi, S. (2012). An exploratory investigation into knowledge management in Western Australian knowledge-intensive small businesses. Retrieved from http://ro.ecu.edu.au/theses_hons/42

This Thesis is posted at Research Online.

http://ro.ecu.edu.au/theses_hons/42 


\section{Edith Cowan University}

\section{Copyright Warning}

You may print or download ONE copy of this document for the purpose of your own research or study.

The University does not authorize you to copy, communicate or otherwise make available electronically to any other person any copyright material contained on this site.

You are reminded of the following:

- Copyright owners are entitled to take legal action against persons who infringe their copyright.

- A reproduction of material that is protected by copyright may be a copyright infringement.

- A court may impose penalties and award damages in relation to offences and infringements relating to copyright material. Higher penalties may apply, and higher damages may be awarded, for offences and infringements involving the conversion of material into digital or electronic form. 
An Exploratory Investigation into Knowledge Management in Western Australian Knowledge-intensive Small Businesses

\section{Shukrullah Fassehi}

A thesis submitted in fulfilment of the requirements of the Bachelor of Business

(Human Resource Management) Honours degree in the School of Management,

Edith Cowan University

24 September 2012 


\section{USE OF THESIS}

This copy is the property of Edith Cowan University. However, the literary rights of the author must also be respected. If any passage from this thesis is quoted or closely paraphrased in a paper or written work prepared by the user, the source of the paper must be acknowledged in the work. If the user desires to publish a paper or written work containing passages copied or closely paraphrased from this thesis, which passages would in total constitute an infringing copy for the purpose of the Copyright Act, he or she must first obtain the written permission of the author to do so. 


\section{ABSTRACT}

From a knowledge management (KM) perspective, organisational effectiveness depends on the organisation's capacity to effectively perform a range of processes that include identifying, acquiring, sharing, and storing valuable knowledge. The literature suggests that the growth of interest in the field of $K M$ is largely centred on large organisations. Small businesses have not received much attention in the literature. This is surprising, given that small businesses (however defined) represent the majority of businesses in most countries and, as is the case in Australia, make a major contribution towards business activity, economic development and employment generation.

This study employed a qualitative exploratory design to investigate two aspects of KM. These are: (1) the processes of identifying, acquiring, sharing and storing knowledge; and (2) the adoption of critical success factors (CSFs) in the KM processes. Data were obtained through semi-structured interviews with eight owners/managers of knowledge-intensive small business in Western Australia.

Findings of the study reveal that knowledge-intensive small businesses have a moderate level of KM understanding. Technology was perceived to be the most common enabler of KM processes, and organisational culture was viewed as the most important factor in fostering $\mathrm{KM}$ processes. Overall, the findings of the study provide a preliminary guiding framework for those small businesses that lack KM awareness. Implications of the study findings for small business owner/managers, small business development agencies and KM practitioners are explained. Furthermore, limitations of the study and avenues for future research are discussed. 


\section{DECLARATION}

I certify that this thesis does not, to the best of my knowledge and belief:

i. Incorporate without acknowledgement any material previously submitted for a degree or diploma in any institution of higher education;

ii. Contain any material previously published or written by another person except where due reference is made in the text; or

iii. Contain any defamatory material.

iv. Contain any data that has not been collected in a manner consistent with ethics approval.

Signature:

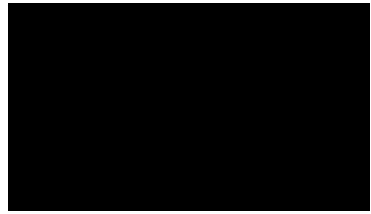

Date: $24 / 09 / 2012$ 


\section{ACKNOWLEDGEMENTS}

It is a great pleasure to thank everyone who contributed in the production of this thesis. First and foremost, I extend my heartfelt gratitude to my supervisor $\mathrm{Dr}$ Alan Coetzer for his dedicated effort and painstaking patience in supervising my thesis. Undoubtedly, without your insightful, detailed, regular and valuable feedback throughout this journey, neither the production of this thesis would have been possible, nor would have I gained the self-confidence and trust in my ability to travel along this journey. I would also like to thank Dr Pattanee Susomrith my co-supervisor for her inspiration and encouragement in supporting me to continue along this journey.

A sincere thank you goes to the owners/managers for their valuable time and commitment in volunteering to participate in the study. Certainly, the production of this thesis would not have been possible without your support.

A special thank you goes to my dear brother Hikmat Fasehi without whose love and support, I would not have been able to continue with my studies. You have been my biggest support throughout my life and study, including this thesis. You have stood right beside me at all stages of my life and have given me the love and support I have needed throughout my life. Certainly, without your support, I would not have gained the level of success I have sought in my life.

With much appreciation, I would like to acknowledge the funding support that was provided by the Edith Cowan University's Executive Dean's Honours Scholarship (Faculty of Business \& Law).

I am also indebted to Troy Fuller - my former lecturer for his motivation and encouragement in pursuing my studies. Your inspirational advice enabled me to take the first step in pursuing Honours. I feel pleased to acknowledge that the first step led me to the final steps, where I can proudly celebrate this milestone. 
I would also like to thank all of my friends namely: Abbas Ehsani, Adila Karimi, Ahmad Ali Shafaq, Arif Ahmady, Amy Conti, Carlton Reid, Ghulam Sakhi Amiry, Hayat Haidari, Jay Piner, Kristy Gamble, Najibullah Hakimi, Suniti Rao, and Vijay Pundir for your constant encouragement throughout writing this thesis. 


\section{TABLE OF CONTENTS}

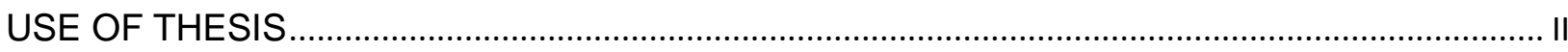

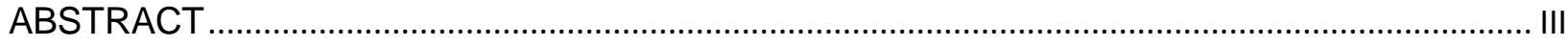

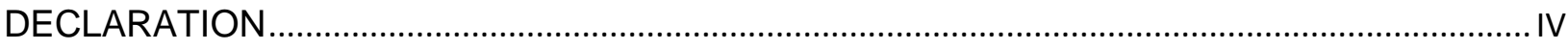

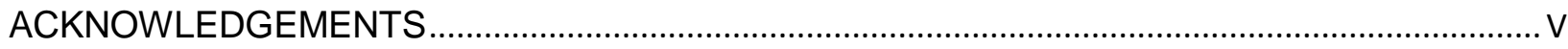

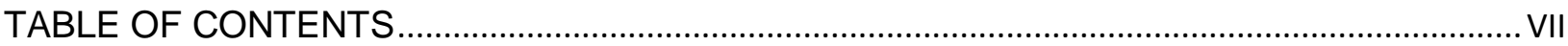

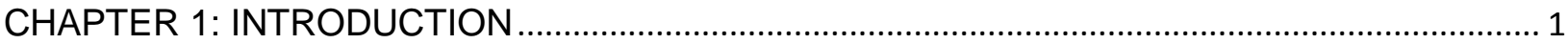

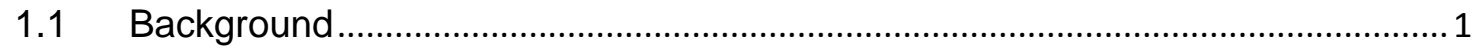

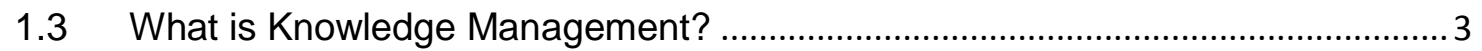

1.4 KM in the Small Business Environment .............................................................. 5



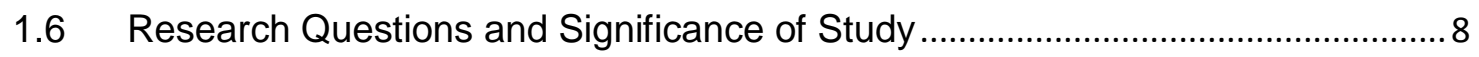

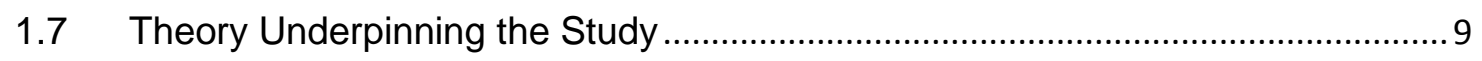

1.8 Critical Success Factors (CSFS) .......................................................................

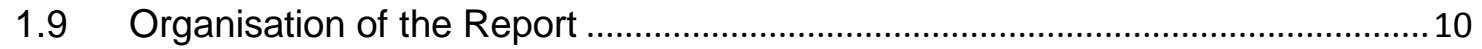

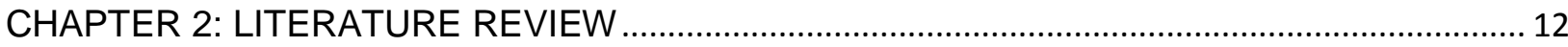

$2.1 \quad \mathrm{KM}$ Processes in Small Businesses................................................................... 12

2.2 Factors Fostering KM in Small Businesses ......................................................... 16

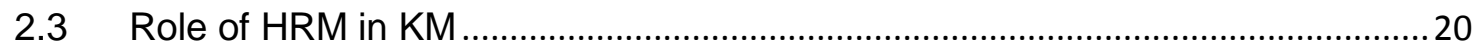

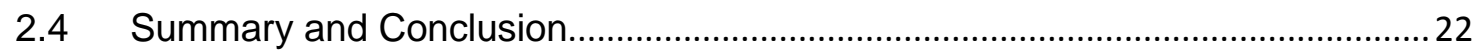

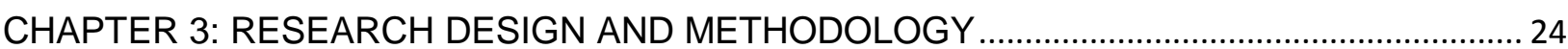

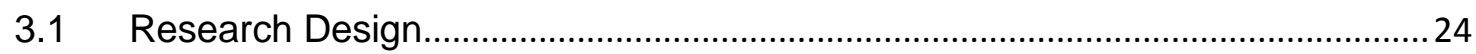

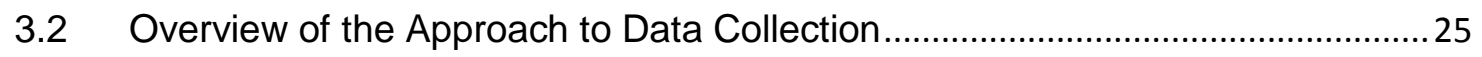

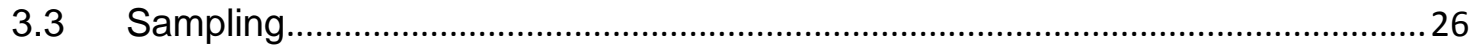

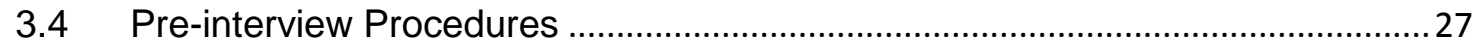

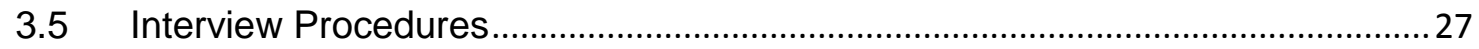

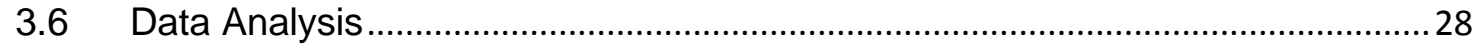

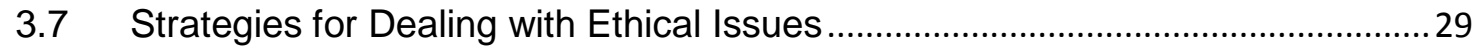

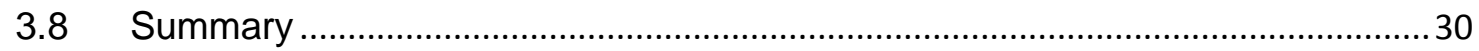

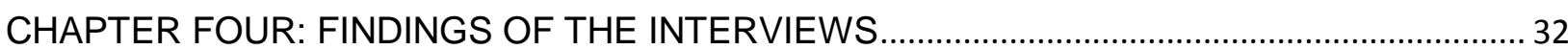

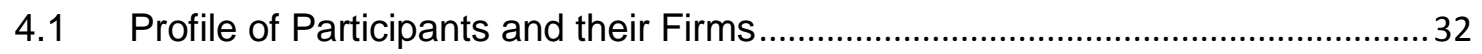

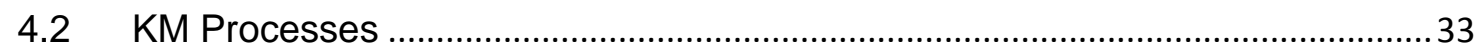

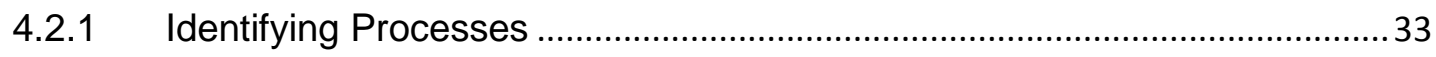

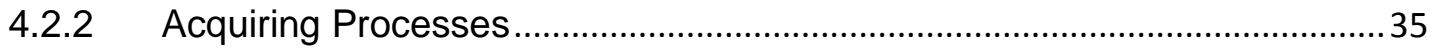




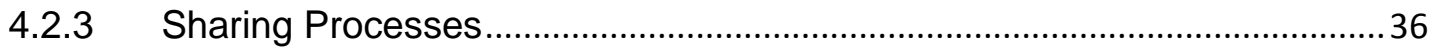

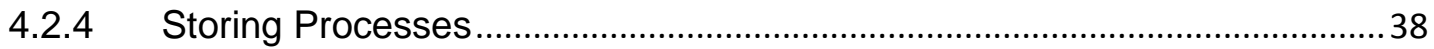



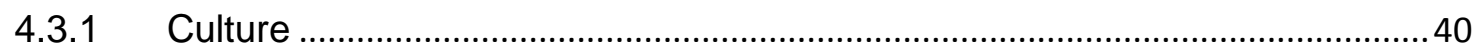

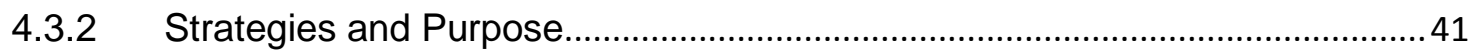

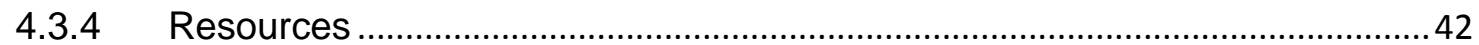

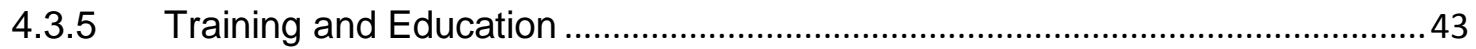

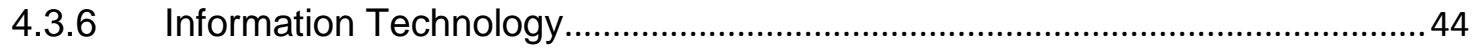

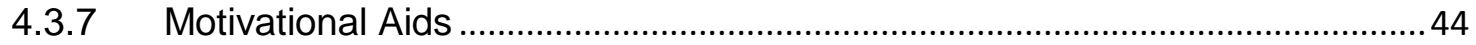

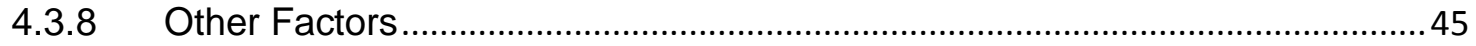

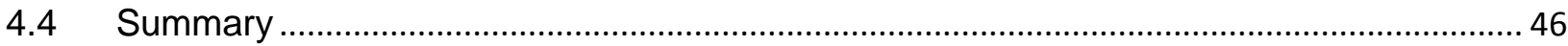

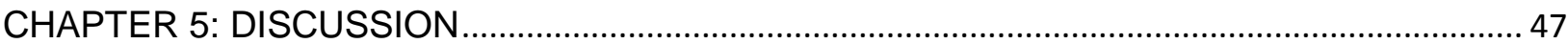

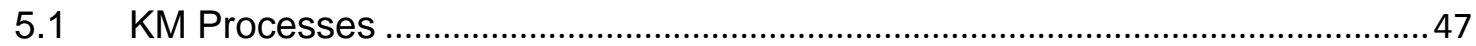

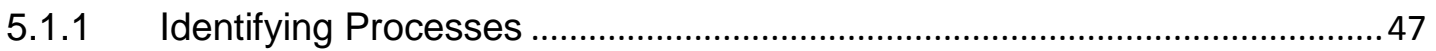

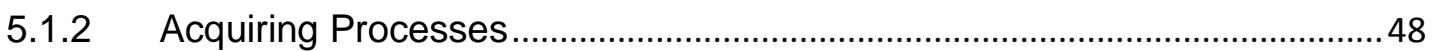

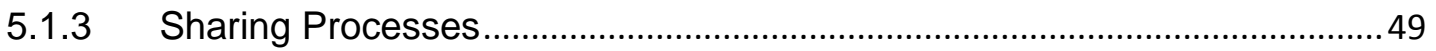

5.1.4 Storing Processes...................................................................................... 51



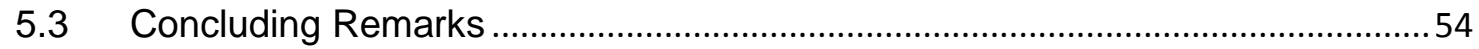

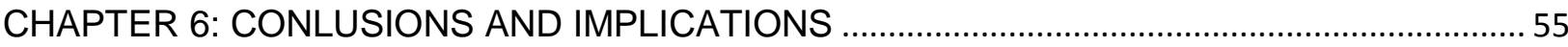

6.1 Conclusions about the Research Questions.......................................................55

6.2 Implications for Small Businesses and Development Agencies ..........................56

6.3 Limitations and Implications for Future Research...................................................57

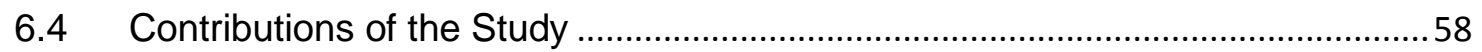

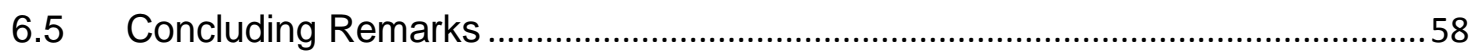

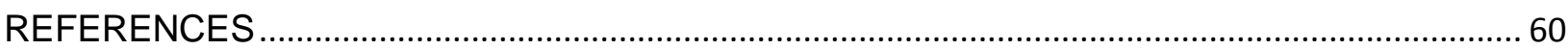

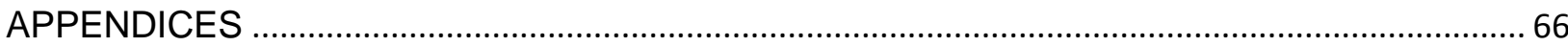

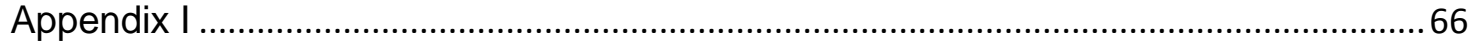

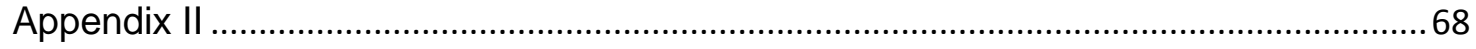

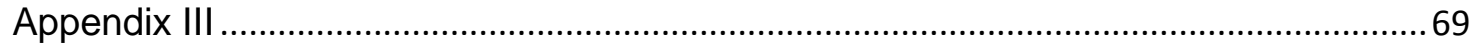



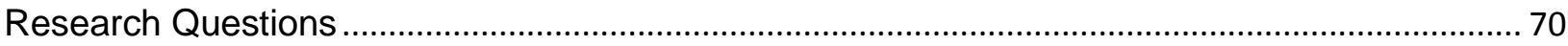




\section{CHAPTER 1: INTRODUCTION}

Chapter 1 begins with background information on knowledge management (KM) and discusses its importance to organisational performance. The chapter then defines KM and distinguishes among data, information and knowledge. Explicit and tacit knowledge are also distinguished. Next, the chapter discusses $\mathrm{KM}$ research in the small business environment, followed by the statement of the research problem portraying the issues associated with the lack of KM research in small businesses. The research questions on the KM processes and the critical success factors (CSFs) that helped to focus this study are presented next, followed by a discussion of this study's significance. Thereafter, the theory that underpins this study (open-systems theory) is outlined followed with a brief description of the CSFs. Lastly, the final section (Organisation of the Report) concludes by providing a brief introduction to subsequent chapters.

\subsection{Background}

Knowledge is perceived to be one of the key driving forces for business success (Wong, 2005). In today's competitive arena, knowledge is considered the most valuable stock in organisations. If it is harnessed and leveraged correctly, it can mobilise organisations to become more adaptive, innovative, intelligent and sustainable (Wong \& Aspinwall, 2004). However, the management of knowledge, particularly over the last decade has turned into a key issue for organisations in all sectors of the economy (Hutchinson \& Quintas, 2008). Some organisations have pioneered the use of $\mathrm{KM}$ to outperform their rivals, whereas others are still struggling to realise its importance. Nonetheless, KM in any organisational setting aims to promote enhanced performance.

The importance and usefulness of $\mathrm{KM}$ has been widely discussed in the literature. Many studies (Amalia \& Nugroho, 2011; Darroch \& McNaughton, 2002; Demarest, 1997; Desouza, 2010; Earl, 2001; Greiner, Bohmann, \& Krcmar, 2007; Lee \& Lan, 2011; Liyanage, Elhag, Ballal, \& Li, 2009; Plessis, 
2007; Quintas, Lefrere, \& Jones, 1997; Sandhawalia \& Dalcher, 2011) suggest that $\mathrm{KM}$ contributes to innovation. Innovation has been defined as the introduction of any new or significantly value added goods, services, processes, or marketing techniques (Statistics New Zealand, 2009), new product, service or technology (Harkema, 2003), and the implementation of a significantly improved good, service, process, marketing, organisational practices, workplace organisation and external relations (Organisation for Economic Cooperation and Development, 2005). Innovation is a key source of economic growth (Australian Bureau of Statistics, 2007) and organisations can achieve this by embracing $\mathrm{KM}$ as a business strategy to innovate and enhance their performance.

Innovation can be introduced and applied to various business activities. Using a sample of 5038 observations from the 2005-06 Business Longitudinal Database (BLD), the Australian Bureau of Statistics (2010) found that the sample businesses generally undertook around 20 per cent of innovation in some aspects of the business functions. For example, 18.5 per cent of the businesses were engaged in goods and services, 22.9 per cent in operation processes, 19.7 per cent in managerial practices, and 15.4 per cent in marketing associated innovation. Similarly, Sandhawalia and Dalcher (2011) also found that organisations develop KM skills and abilities to support a range of their important operational and innovative functions. $\mathrm{KM}$ also aims to access organisational knowledge to develop better services, thus creating and sustaining capabilities and competitive advantage (Johnston \& Paladino, 2007).

Effective use of KM enhances innovation (Darroch \& McNaughton, 2002; Sandhawalia \& Dalcher, 2011) and enables organisations to meet the fast changing customer demands (Sandhawalia \& Dalcher, 2011). KM supports organisations to be faster, more efficient and innovative than their competitors (Greiner et al., 2007), which enables organisations to deliver innovative products and services to customers (Fink \& Ploder, 2009b). In today's fierce competition, businesses are compelled to innovate so as to prosper, even to survive in the global marketplace (Xu, Houssin, Caillaud, \& Gardoni, 2010). 
This suggests that achieving and maintaining competitive edge in the marketplace is strongly associated with an organisation's capacity to innovate.

Apart from innovation, other purported benefits of $\mathrm{KM}$ include efficiency improvements (Jarrar, 2002; Wei, Choy, \& Chew, 2011), improved decision making (Earl, 2001; Frey, 2001; KPMG, 1998; Liyanage et al., 2009; Wei et al., 2011), improved business processes, reduced duplication of work and increased profitability (Lee \& Lan, 2011), organisational adaptability and renewal (Earl, 2001), developed sustainable competitive advantage (Wong \& Aspinwall, 2004), stimulated learning, facilitated collaboration and networking (Liyanage et al., 2009),faster response time, increased profit and improved productivity (KPMG, 1998), and business growth (Salojarvi, Furu, \& Sveiby, 2005). Thus, organisations that effectively apply KM processes are likely to reap better outcomes in the long term.

\subsection{What is Knowledge Management?}

There is a wide range of definitions of $\mathrm{KM}$ in the literature. For instance, Alavi and Leidner (2001) define KM as the four fundamental processes of knowledge creation, storage, transfer, and application. Omerzel et al. (2011) view KM in distinct functions of acquiring, creating, developing, storing, and practically utilising knowledge. Further, KM has been defined as the processes of creating, sharing and disseminating knowledge (Keen \& Tan, 2007), the capability of creating, organising, storing, retrieving, transferring, and applying knowledge (Carlsson, 2003), and the processes of identifying, acquiring, distributing, and preserving knowledge (Fink \& Ploder, 2009b). These definitions suggest that $\mathrm{KM}$ is mainly concentrated on how businesses identify, acquire, create, share, apply and store knowledge. However, the key questions to be asked are: (1) what is knowledge? (2) How is knowledge interpreted and categorised? Understanding knowledge and its interpretations and categorisations helps one in defining $\mathrm{KM}$ and its objectives.

The issue of defining knowledge has dwelled in minds of philosophers since the traditional Greek era and has led to various epistemological debates (Alavi \& 
Leidner, 2001). Some authors, mostly in the IT literature address the issue of defining knowledge by differentiating it between information and data (Alavi \& Leidner, 2001). Many researchers claim that data, information, and knowledge are part of a sequential order (Zins, 2007). As such, "data are the raw material for information, and information is the raw material for knowledge" (Zins, 2007, p. 1). A common observation suggests that data are raw facts and numbers such as summarised facts and figures which are acquired from experiments, processes, surveys, etc(Freeze \& Kulkarni, 2007), whereas information is a processed and interpreted version of data (Alavi \& Leidner, 2001).

Knowledge has also been interpreted in several ways. For instance, Alavi and Laidner (2001) define it as personal information that has been processed in the minds of humans. Other definitions view it as a thought in an individual's mind that is justified by his/her belief that it is true (Zins, 2007), and information that is interpreted by people and then used to meet the purpose of the interpretation (Liyanage et al., 2009). The ultimate use of knowledge is to make an informed decision which in an organisational context may potentially lead to enhanced performance, economic prosperity, and customer satisfaction.

Knowledge is commonly categorised as either tacit or explicit (Liyanage et al., 2009). The distinction between tacit and explicit knowledge was first made by Polanyi (1962). Explicit knowledge has been defined as knowledge that is objective and is based on logic (Sutton, 2001), systematic and easily transmitted from individual to individual using language (Stacy, 2000), can be expressed in words and numbers (Nonaka \& Konno, 1998) and can be classified easily (Grover \& Davenport, 2001). Tacit knowledge has been defined as being highly personalised and difficult to formalise (Nonaka \& Konno, 1998), subjective and experiential (Sutton, 2001), personal and difficult to put into written form (Holste \& Fields, 2010), mental models underneath the consciousness level that is being displayed as skills (Stacy, 2000), and one that is rooted in an individual's mind that cannot be communicated easily (Grover \& Davenport, 2001). 
The distinction between tacit and explicit knowledge makes KM a challenging phenomenon. Although tacit and explicit knowledge are both important, Western organisations have particularly focused on managing explicit knowledge (Grover \& Davenport, 2001). Abeson and Taku (2006) found that tacit and explicit knowledge are both important in decision making. It is imperative that organisations pay equal attention to both explicit and tacit knowledge in order to make best use of their knowledge assets.

\subsection{KM in the Small Business Environment}

KM has recently gained considerable support in the literature (Vorakulpipat \& Rezgui, 2008). It has attracted increasing attention since the mid-1990s (Hislop, 2010; Massey, Ramesh, \& Montoya-Wiss, 2005). The recent studies show that the growth of interest in $\mathrm{KM}$ is largely centred on larger organisations (Hutchinson \& Quintas, 2008). Previous studies in the field of KM have not focused on features, characteristics and conditions of small businesses (Wong \& Aspinwall, 2004). According to Desouza and Awazu (2006), small-to-mediumsized enterprises (SMEs) do not manage knowledge the way larger organisations do. KM in SMEs is enacted via social interactions (Desouza \& Awazu, 2006) rather than employing sophisticated technologies. Furthermore, SMEs have some distinct features as compared to large businesses (Bozbura, 2007; Wong \& Aspinwall, 2004). For instance, small businesses adopt informal KM processes (Hutchinson \& Quintas, 2008), and KM processes are not generally documented. Owners in SMEs focus mainly on the operational side of the business which makes it challenging to concentrate on KM strategies.

One of the challenges in comparing research findings of studies that have examined $\mathrm{KM}$ in SMEs relates to definitional issues. Defining an SME is complicated, and there is no widely accepted definition (Coetzer, Cameron, Lewis, Massey, \& Harris, 2007). Small and medium enterprises have been defined differently in various countries. In fact, there is no single definition of SMEs (Organisation for Economic Co-operation and Development, 2002). Table 1.1 illustrates how small business is defined in various national contexts. 
Table 1.1Definitions of Small Businesses

\begin{tabular}{|c|c|c|}
\hline Definitions & Country/region & Sources \\
\hline $\begin{array}{l}\text { Small business is an enterprise } \\
\text { employing less than } 20 \text { employees }\end{array}$ & Australia & $\begin{array}{l}\text { Australian Bureau of } \\
\text { Statistics }\end{array}$ \\
\hline $\begin{array}{l}\text { SMEs are enterprises with } 19 \text { or less } \\
\text { employees }\end{array}$ & New Zealand & $\begin{array}{l}\text { Ministry of Economic } \\
\text { Development }\end{array}$ \\
\hline $\begin{array}{l}\text { Small businesses are those employing } \\
\text { less than } 500 \text { employees }\end{array}$ & USA & $\begin{array}{l}\text { Small Business } \\
\text { Administration }\end{array}$ \\
\hline $\begin{array}{l}\text { Small businesses are those employing } \\
\text { less than } 50 \text { employees }\end{array}$ & UK & $\begin{array}{l}\text { Department of Business } \\
\text { Innovation and Skills }\end{array}$ \\
\hline $\begin{array}{l}\text { Small businesses in the European Union } \\
\text { are those employing less than } 50\end{array}$ & European Union & $\begin{array}{l}\text { Organisation for Economic } \\
\text { Co-operation and }\end{array}$ \\
\hline employees & & Development \\
\hline
\end{tabular}

As indicated in Table 1.1, in Australia, small business is defined as a business employing less than 20 people (Australian Bureau of Statistics, 2001). Whereas, in New Zealand, businesses employing 19 or less employees are classified as SMEs (Ministry of Economic Development, 2010). In the European Union, small businesses employ less than 50 employees (Organisation for Economic Co-operation and Development, 2002) which is similar to the UK (Department for Business Innovation \& Skills, 2010). In the USA, small businesses are those employing less than 500 employees (Small Business Administration, 2010). Apart from differences of small businesses in size, they are also different in characteristics, ideals and needs from large businesses (Wong \& Aspinwall, 2004). These differences make it challenging to compare $\mathrm{KM}$ studies in small businesses in order to suggest a uniform model that could fit small businesses and SMEs.

It is essential to note that small businesses should not be considered less important and influential than large ones (Wong \& Aspinwall, 2004). The small business sector is a great contributor to a country's economic well-being. SMEs play a key role in the Australian economy (Australian Bureau of Statistics, 2010). In the OECD countries, SMEs account for a significant portion of economic well-being (Organisation for Economic Co-operation and Development, 2002). In June 2007, SMEs accounted for about 42 per cent of total employment in Australia, and estimated to have contributed around 46 per 
cent of Australia's Gross Domestic Product (GDP) in 2006 (Australian Bureau of Statistics, 2010). SMEs in New Zealand accounted for 30.6 per cent of total employment in 2009 (Ministry of Economic Development, 2010). In 2009, small business in the UK employed an estimated 22.8 million people and secured 58.9 per cent of private sector employment with an estimated annual turnover of $£ 3,200$ billion (Department for Business Innovation \& Skills, 2010). In the United States, the small business sector accounted for about half of the country's private sector workforce (Small Business Administration, 2010). These statistics suggest that small businesses are important generators of economic security and prosperity worldwide. Therefore, it is essential to study factors that may potentially enhance SMEs' business performance.

\subsection{Statement of the Research Problem}

Having established the significance of small businesses to national economies (Australian Bureau of Statistics, 2010; Department for Business Innovation \& Skills, 2010; Ministry of Economic Development, 2010), it is vital to promote and enhance the KM awareness and capabilities of these businesses to further their success. The lack of KM studies in the SME environment (Fink \& Ploder, 2009b; Hutchinson \& Quintas, 2008; Wong \& Aspinwall, 2004, 2005) provides a rationale for the current research to focus on $\mathrm{KM}$ in the small business context as opposed to larger businesses.

A lack of KM research in the small business context is problematic, especially for those small business owners/managers and KM practitioners (e.g., business consultants and training providers) who are keen to effectively implement KM practices. Developing knowledge through research projects that examine KM in small businesses will generate findings that will assist these small business owners/managers and $\mathrm{KM}$ practitioners to develop strategies to leverage knowledge more effectively and provide practical guidance to small businesses and $\mathrm{KM}$ practitioners in implementing $\mathrm{KM}$ strategies. 


\subsection{Research Questions and Significance of Study}

The current study addresses the following questions:

1. How do the selected Western Australian small businesses identify, acquire, share and store knowledge?

2. What effects, if any, does the extent of critical success factors (CSFS) adoption have on the processes of identifying, acquiring, sharing and storing knowledge?

The processes of identifying, acquiring, sharing, and storing knowledge are fundamental steps in implementing a KM strategy (RQ1). In addition to focusing on the KM processes, the study also seeks to investigate the effects of the CSFs on the KM processes in small businesses (RQ2). The CSFs are a list of principles that assist small businesses to successfully implement the KM processes. The CSFs are discussed in greater detail in Chapter 2.

Key terms that are used in the present study are small business, knowledge and KM which are defined as follows. Small business is defined as an enterprise employing less than 20 employees (Australian Bureau of Statistics, 2001). Knowledge is defined as "knowledge in the business about customers, products, processes, competitors and so on, which can be 'locked away' in people's minds or filed on paper or in electronic form" (KPMG, 1998, p. 5). KM refers to a systematic and organised attempt (KPMG, 1998), and a bundle of principles, models, approaches, techniques, and tools that allows businesses to develop and exploit knowledge (Carlucci \& Schiuma, 2006).

The significance of the present study is the contribution that it makes to developing an understanding of $\mathrm{KM}$ in two key topic areas of $\mathrm{KM}$, namely $\mathrm{KM}$ processes and the CSFs. The investigation into these two topic areas (KM processes and CSFs) in a small business context is the first in Western Australia. The findings of the investigation cast light on the approaches to KM in small businesses and provide practical guidance and assistance to small 
businesses in their KM endeavours. As noted previously, knowledge assets are key factors responsible for organisational innovation and effective management (Delgado-Verde, Castro, \& Navas-Lopez, 2011). Small businesses can develop the capacity to enhance their knowledge assets by effectively implementing $\mathrm{KM}$.

\subsection{Theory Underpinning the Study}

The theory underpinning the current study is open-systems theory. Opensystems theory posits that organisations are dependent on the external environment for resources (raw materials, employees, financial resources, information, and equipment) (McShane, Olekalns, \& Travaglione, 2010). Openness to the external environment assists organisations in introducing fresh perspectives, ideas and values. Furthermore, the emphasis of the opensystems theory on an organisation's system character (movement in one part of an organisation leads to movement in other parts) (Wright \& Snell, 1991) encourages organisations to be responsive to internal change that has the potential to influence organisational performance. Therefore, it could be contended that organisations as open systems gain sustainable improvements such as adapting to varying customer demands and developing proactive strategies in dealing with market competition by adopting the open-systems perspective.

In today's organisations where the primary input is knowledge (McShane et al., 2010), acquiring knowledge internally and externally assists organisations in identifying opportunities for growth. Growth opportunities could be identified and capitalised through adopting a KM strategy which continually encourages organisations to acquire, share and use knowledge. Examples of acquiring knowledge could be customer surveys, research and development activities, reviewing performance, and analysing competitors' products (Huber, 1991). Small businesses in particular may use customer surveys, research and development activities, performance reviews, and analysis of competitors' products/services to enhance the quality of customer service, developing 
innovative processes, fostering staff morale, and promoting better products/services.

\subsection{Critical Success Factors (CSFs)}

Critical success factors (CSFs) are components that contribute to an organisation's success by building knowledge-based competencies (Muhammed, Doll, \& Deng, 2009). The CSFs in the context of KM are discussed in this thesis with details in Chapters 2, 4, and 5. The CSFs that contribute to enhanced performance in $\mathrm{KM}$ were investigated in a study by Wong and Aspinwall (2005). The CSFs as found by Wong and Aspinwall are the 11 principles which provide guidelines for small businesses in successfully adopting and implementing KM practices. These CSFs are: management leadership and support, culture, strategies and purpose, resources, processes and activities, training and education, human resource management, information technology, motivational aids, organisational infrastructure, and measurement.

\subsection{Organisation of the Report}

This report comprises six chapters. The study of KM in selected Western Australian small business continues in the remaining chapters. Chapter 2 reviews the literature regarding KM in small businesses. The chapter develops the background regarding what has already been studied in the KM literature on small businesses and provides a rationale for the current study. The central focus of the KM literature review is on small businesses and is structured around the four KM processes (identifying, acquiring, sharing and storing knowledge) and the CSFs. Chapter 3 explains and justifies the methodological approach used in this study to collect, collate, analyse and present the evidence in order to address the research questions. Chapter 4 presents the findings of the interviews in the form of key themes and patterns that emerged from analysis of the data. Chapter 5 discusses the findings of the interviews in relation to the extant literature of KM in small businesses. Lastly, Chapter 6 
draws conclusions about the research questions and makes suggestions for future research. 


\section{CHAPTER 2: LITERATURE REVIEW}

The literature on KM in SMEs suggests that research has focused on primarily two topic areas. These are: (1) KM processes; and (2) factors that foster (or deter) KM. The review of KM literature that follows begins with an analysis of the literature on KM processes in small businesses. This involves an analysis of the general $\mathrm{KM}$ processes and those processes that small businesses are thought to employ in their KM endeavours. The review of the literature on KM processes is followed by an overview of the literature that discusses factors that foster (or deter) KM in small businesses. Thereafter, the role of HRM in KM is discussed. The review of the literature concludes by drawing upon the contributions and limitations of the literature to generate research questions for the current study.

\subsection{KM Processes in Small Businesses}

An important step in studying KM is to investigate its processes. Probst, Raub and Romhardt (2002) found that there are eight key KM processes and these processes are known as the building blocks of KM. These are knowledge: identification, acquisition, development, distribution and sharing, utilisation, preservation, assessment and goals. Fink and Ploder (2009b) in studying KM in SMEs found that SMEs are characterised by four KM processes of knowledge: identification, acquisition, distribution/sharing and preservation. This review focuses on the four KM processes in SMEs identified by Fink and Ploder. The key reason for focusing on the four KM processes is that they are relevant to SMEs. Other sources from the literature have also been integrated in the literature review. Table 2.1 illustrates the four KM processes defined by Probst et al. which Fink and Ploder identified to be relevant to SMEs.

Understanding the KM processes as shown in Table 2.1, is a fundamental step in making $\mathrm{KM}$ a successful endeavour. This generally means that $\mathrm{KM}$ activities in SMEs are guided by employing the four KM processes. It is important that SMEs identify the key sources of knowledge, experience and know-how in order to maintain competitiveness in the market (Fink \& Ploder, 2009a). The 
identification of key sources of knowledge should lead to its acquisition in order to feed value to an organisation's existing knowledge.

Table 2.1 KM Processes in SMEs

\begin{tabular}{|c|c|}
\hline KM Processes & Definition \\
\hline Identification & $\begin{array}{l}\text { The process of identifying external knowledge to analyse and } \\
\text { describe an organisation's knowledge environment }\end{array}$ \\
\hline Acquisition & $\begin{array}{l}\text { The extent to which an organisation has the potential to gather } \\
\text { knowledge through relationships with customers, suppliers, } \\
\text { competitors, and partners in co-operative ventures }\end{array}$ \\
\hline Distribution/sharing & $\begin{array}{l}\text { The process of sharing and spreading knowledge that is already } \\
\text { present in an organisation }\end{array}$ \\
\hline Preservation & $\begin{array}{l}\text { The selective retention of information, documents, and } \\
\text { experiences required by an organization }\end{array}$ \\
\hline
\end{tabular}

It is also imperative that individuals share knowledge to extend its usability and significance across an organisation. SMEs are categorised by smaller groups, thus a culture of sharing knowledge is paramount (Fink \& Ploder, 2009a) to enhance organisational effectiveness. Furthermore, it is also necessary that SMEs have an effective knowledge retention strategy to store knowledge. This helps organisations to access relevant knowledge when needed.

In a separate study, Fink and Ploder (2007) investigated cost-efficient software that support the identified KM processes of knowledge: identification, acquisition, transfer/sharing, and preservation. It was found that the highest ranked method of knowledge identification in SMEs is knowledge balance (Fink \& Ploder, 2007). The authors do not explain the meaning of knowledge balance; however, it is assumed that it is a multi-source of knowledge identification. The favourite method of acquiring knowledge in SMEs is search engine followed by brainstorming and knowledge network (Fink \& Ploder, 2007). E-mail systems and databases are the highest ranked methods of distributing and preserving knowledge respectively (Fink \& Ploder, 2007). Fink and Ploder (2009b) acknowledge that while information technology infrastructure is the key dimension of $\mathrm{KM}$, the social and cognitive side should 
also be considered. However, Desouza and Awazu (2006) disagree that technology is an important means to manage knowledge in SMEs and emphasise that technology should never be considered part of the KM strategy in SMEs.

Desouza and Awazu (2006) found that KM in SMEs is enacted via social interactions such as face-to-face meetings, observations, and apprenticeship training. In particular, face-to-face discussions are found to be the most common tool and/or technology for transferring knowledge (Wei et al., 2011). Technology in SMEs is limited to the use of cash registers and storing employee contact information on databases (Desouza \& Awazu, 2006). Knowledge in SMEs is instantly put into practice rather than being stored on databases (Desouza \& Awazu, 2006). For technology to assist KM processes, there should be a foundation to rest on (Desouza \& Awazu, 2006), and that is the human and social aspects that come first. Indeed, the natural birth of knowledge takes place in human minds. "Organizations often fail to acknowledge that it is the people, not technologies that are the source of knowledge" (Nakra, 2000, p. 54).

The study by Wei et al. (2011) is among the most recent that has extensively examined KM in SMEs. In this study, 350 questionnaires were sent to managers and/or owners in Malaysian SMEs based on convenience sampling with a response rate of 20 per cent (Wei et al., 2011). They claim that their study is perhaps among the first to investigate KM processes with in-depth investigation in SMEs.

Wei et al. (2011) discovered external training and in-house training to be the first and second most important ways of acquiring knowledge in SMEs. Hiring new employees scored the lowest mean (Wei et al., 2011), which validates the claim by Desouza and Awazu (2006) who found that SMEs rarely have the capabilities to recruit the best minds. Hence, employees must be trained and taught (Desouza \& Awazu, 2006), to gain enough knowledge, skills and expertise necessary for the business. Lee and Lan (2011) found that SMEs 
have the procedures to acquire new product/service and competitors' associated knowledge within the industry.

Additionally, Wei et al.(2011) found that the most common method of sharing knowledge in SMEs is face-to-face discussion followed by e-mail and intranet. Whereas, the findings of the study by Fink and Ploder (2007) suggest that sharing knowledge in SMEs is technology based. Employees in SMEs are in close proximity with the owner/manager; thus knowledge is shared via personalised meetings and conversations (Desouza \& Awazu, 2006). Other methods of sharing knowledge include computerised directory of experts, discussion forum, knowledge repository, computer conferencing and teleconferencing, decision support tools and video conferencing (Wei et al., 2011). However, as evident from research, knowledge sharing in SMEs is more common through face-to-face communication rather than technology.

Preserving knowledge is also an important aspect of KM. When an employee leaves an organisation, he/she takes knowledge out the door (Desouza \& Awazu, 2006). In order to protect knowledge, organisations should have policies to ensure the safety of knowledge assets at all time (Lee \& Lan, 2011). Surprisingly, Desouza and Awazu (2006) found that SMEs do not suffer knowledge loss due to the fact that much of the core knowledge is held by the owners/managers of SMEs. All employees have common knowledge about organisations (Desouza \& Awazu, 2006). Further, it was found that if one or more employees leave, the organisation is not affected, as other employees can cover their positions (Desouza \& Awazu, 2006). However, it still costs organisation to train and prepare employees to do as well as the previous employees.

A study by Hutchinson and Quintas (2008) examined the distinction of KM processes between large organisations and SMEs. These authors formulated two propositions that: (1) knowledge is managed in organisations without using the terminology of KM and formal KM structures (also called informal KM); and (2) that small businesses are more likely to adopt informal processes to manage knowledge. In-depth, semi-structured interviews were used to 
investigate the KM practices. Hutchinson and Quintas (2008) found that all respondents described behaviours and activities within their businesses that revealed some, if not all, of the $\mathrm{KM}$ processes. This suggests that many organisations implement KM without the use of terminology or language of KM, and small businesses in particular, adopt informal rather than formal KM practices to manage knowledge (Hutchinson \& Quintas, 2008). Even though KM activities take place in small businesses, few managers label them 'knowledge management' (Salojarvi et al., 2005). These studies support the findings by uit Beijerse (2000) in which the authors found that only 50 per cent of the SMEs employed formal KM processes. Many formal KM approaches focus on technological as opposed to person-based systems which are costly and specifically designed for larger organisations (Hutchinson \& Quintas, 2008). That is why small businesses consider the formal KM approach as an expense rather than an investment.

\subsection{Factors Fostering $\mathrm{KM}$ in Small Businesses}

Effective KM implementation in SMEs depends on a number of factors. The study by Wong and Aspinwall (2005) investigated the critical success factors (CSFs) for KM in SMEs. In their study, Wong and Aspinwall (2005) used a postal survey method in which data was collected from SMEs in the UK. In addition, views regarding CSFs were collected from a group of academics, consultants and $\mathrm{KM}$ practitioners in order to provide a more comprehensive view of CSFs. The CSFs are shown in Table 2.2 in order of importance as found by Wong and Aspinwall (2005). The discussion that follows Table 2.2 is arranged in the same order as the CSFs presented in the table.

Table 2.2 Wong and Aspinwall's CSFs

$\begin{array}{ll}\text { Management leadership and support } & \text { Culture } \\ \text { Strategies and purpose } & \text { Resources } \\ \text { Processes and activities } & \text { Training and education } \\ \text { Human resource management } & \text { Information technology } \\ \text { Motivational aids } & \text { Organisational infrastructure } \\ \text { Measurement } & \end{array}$

Leadership and support: Wong and Aspinwall (2005) found management leadership and support as the most important factor in fostering KM in SMEs. 
Successful KM requires proactive support and leadership from top management (Wong \& Aspinwall, 2005), which lay a foundation for KM. Like every change program, KM can benefit from management support (Davenport, De Long, \& Beers, 1998). Leaders should demonstrate willingness to share and offer their knowledge (Wong, 2005) and promote a mindset that emphasises cooperation and knowledge sharing across organisations (Wong \& Aspinwall, 2005). This builds a culture that encourages KM initiative as a team effort as opposed to individual effort.

Culture: This is the second most important factor which "indicates that a knowledge-friendly cultural foundation is certainly more important than the deployment of information technology in KM" (Wong \& Aspinwall, 2005, p. 75). A knowledge-friendly culture is one of the most important factors of $\mathrm{KM}$ success, yet one of the most difficult to create (Davenport et al., 1998). It is necessary that organisations be proactive in building a culture that promotes $\mathrm{KM}$. A culture that promotes $\mathrm{KM}$ is one that values knowledge and encourages its creation, sharing and application (Wong, 2005). The primary aim of culture vis-a-vis $\mathrm{KM}$ is to motivate people to make use of their knowledge productively (uit Beijerse, 2000). This is possible when organisations demonstrate effective leadership and employ strategies and policies that guide KM initiatives.

Strategy and purpose: This is the third most important factor that clarifies the need for pursuing KM (Wong \& Aspinwall, 2005). KM strategy is one of the key success factors of KM (Liebowitz, 1999) which enables an organisation to deploy its capabilities and resources in order to achieve its $\mathrm{KM}$ objectives(Akhavan, Jafari, \& Fathian, 2006). Similarly, Bozbura (2007) found policies and strategies as the most important contributors to KM in SMEs. This is due to the fact that policies and strategies set guidelines and articulate a set of expectations which are to be adhered to.

Resources: This is the fourth most important criterion for KM adoption. The success of KM depends on resources (Wong, 2005). Wong and Aspinwall (2004) in a qualitative study examined the characteristics of small businesses and found that small businesses lack time, knowledge, expertise, and financial 
and human resources. Wong (2005) referred to resources as financial support, human resources and time. SMEs suffer from resource scarcity (Organisation for Economic Co-operation and Development, 2002), and do not have enough funds to spend on land, labour and capital (Desouza \& Awazu, 2006). Due to resource paucity, allocation and management of available resources are important in adopting KM in SMEs (Wong \& Aspinwall, 2005).

Processes and activities: This is the fifth most important criterion for KM. Probst et al. (2002) found that the key KM processes are knowledge: identification, acquisition, development, distribution and sharing, utilisation, preservation, assessment and goals. Fink and Ploder (2009b) found that the key KM processes that apply to SMEs are knowledge: identification, acquisition, distribution/sharing, and preservation. It is important that appropriate $\mathrm{KM}$ processes are implemented in a systematic and organised manner (Wong, 2005). For instance, when sharing knowledge, technological networking tools should be accompanied with face-to-face communication to make the medium of knowledge transfer richer (Wong, 2005). Furthermore, the researcher suggests $\mathrm{KM}$ processes should be integrated with the daily activities of an employee so as to make KM practices common across an organisation. The integration of KM processes with other work activities of an employee allows an organisation to make effective use of the employee's knowledge, skills and expertise.

Training and education: This is the sixth most important factor in fostering KM. Training provides awareness and understanding of KM to organisational members (Wong, 2005) which facilitates KM implementation. Research suggests that small businesses prefer learning through an informal and social approach as well as favour the knowledge that can easily and quickly be applied to solve their problems (Bishop, 2011). Small businesses develop skills and capabilities informally through ad hoc interactions within informal networks (Palakshappa \& Gordon, 2007; Zhang \& Hamilton, 2009). These networks generally include suppliers, customers, family, friends, and business colleagues and peers (Bishop, 2011) who also engage in KM related activities and training in small businesses. 
Human resources: This is the seventh criterion of $\mathrm{KM}$ as shown in Table 2.2. Human resources is perhaps more important than it has appeared in the literature. Barrett, Mayson and Warriner (2008) argued that human resource management (HRM) practices are a source of competitive advantage that leads to enhanced organisational performance. A study by Edvardsson (2008) revealed that HRM and general strategies of an organisation frame its KM strategies. A lack of human resources in small businesses makes it challenging to implement KM (Wong \& Aspinwall, 2004) because human resources are the key facilitators of KM. Whilst HRM is vital for KM in many ways, the key focus is on employee recruitment, development and retention (Wong, 2005). Furthermore, integrating knowledge-oriented job descriptions, motivational approaches, and evaluation and reward systems into HRM systems (Davenport \& Volpel, 2001) enhance KM capacity in organisations. Small businesses in particular need to consider HRM as a fundamental step in developing capacity to adopt KM.

Information technology (IT): IT is widely considered as a CSF to KM strategies (Sivaramakrishnan, Delbaere, Zhang, \& Bruning, 2010). It has the capacity to enable rapid search, access and retrieval of information (Wong, 2005), and can enhance collaboration and communication across organisations (Sivaramakrishnan et al., 2010; Wong, 2005). IT plays a key role in the processes of storing, categorising, and mapping knowledge (Wei et al., 2011). However, IT should not be considered as an absolute answer to KM as it is only a tool (Wong \& Aspinwall, 2005). Desouza and Awazu (2006) argue that due to resource constraints, SMEs do not consider IT as a solution to KM problems. Instead, SMEs rely on informal meetings and job rotations across all facets of the business (Desouza \& Awazu, 2006) to promote KM practices. Conversely, large organisations have a dedicated department for IT to manage knowledge at least to a surface level. An effective KM system is one that integrates people, processes, technology and the infrastructure (Fink \& Ploder, 2009a).

The three last CSFs of KM; motivational aids, organisational infrastructure, and measurement are also important, and should not be underestimated. Motivational aids encourage individuals in sharing and applying knowledge 
(Wong, 2005) and should be in line with general evaluation and compensation structure (Davenport et al., 1998). Further, by establishing a set of roles such as chief knowledge officer (CKO) and groups, organisations can build KM infrastructure (Davenport et al., 1998). Whilst large organisations have resources to establish layers of $\mathrm{KM}$ roles, SMEs need to initiate $\mathrm{KM}$ on a smaller scale (Wong, 2005). This could be underpinned through employee involvement in discussions and gatherings in which knowledge can be captured and documented. The reason why measurement was considered the least important was because participants in SMES lacked knowledge, skills and expertise in implementing KM (Wong \& Aspinwall, 2005). This indicates that SMEs lack the capacity to measure the KM implementation in order to assess its usefulness and effectiveness.

It is important to note that mismanagement of the 11 CSFs discussed above can also work as deterrents to KM in small businesses. Wei et al. (2011) found that lack of top management commitment, organisational culture, incentive systems, and problems with lack of ownership are among the key constraints of KM success in SMEs. Open structure and friendly physical layout (Wei et al., 2011) should be developed to create a basis for KM. Furthermore, KM should be aligned with the strategic goals of an organisation in order to provide a framework for success and enhanced organisational performance.

\subsection{Role of HRM in KM}

HRM is an important function of organisations and it has the potential to influence the quality of organisational performance (Boxall, 2012). Edvardsson (2008) asserts that the HRM strategies and general strategies of an organisation form its overall KM strategies. Studies suggest that certain HRM practices can foster employee motivation and commitment enabling organisations to leverage knowledge more effectively (Theriou \& Chatzoghlou, 2008). For example, employing the following HR processes and practices are critical to what is termed 'knowledge-intensive situations' (Swart, Kinnie, \& Purcell, 2003): 
- the processes of attracting, developing, rewarding, and retaining human capital;

- recognising the significance of social capital, and;

- building network management skills.

According to Baron (2011), human capital is the knowledge, skills and experience of individuals as well as their willingness to share these attributes within an organisation in creating value. Research suggests that HRM and KM share inseparable commonalities. For example, attracting talented people is a key method of acquiring knowledge (Ivan \& Eleni, 2007) and this process is purely a HRM function. The attraction and retention of employees involve the deployment of certain HRM strategies and these are attractive remuneration (e.g., overtime pay, bonuses, profit sharing), desirable working conditions (e.g., employee assistance program, family-friendly organisational culture, high safety) and access to training and development opportunities (Hutchings, De Cieri, \& Shea, 2011). Implementing desirable HRM strategies has positive impact on employee job satisfaction. Janz and Prasarnphanich (2003) contend that employee satisfaction is a key issue for organisations that aim to create and retain knowledge.

The role of HRM in knowledge transfer can be viewed in its capacity to develop an open and friendly culture that promotes knowledge sharing. Indeed, the transfer of knowledge within an organisation is primarily dependent on its culture (uit Beijerse, 2000). Organisations that are keen to gain competitive advantage need to create and sustain a culture that encourages knowledge sharing. To facilitate the transfer of individuals' knowledge, skills, and experience, organisations need to implement an effective reward and recognition system. An organisation's reward and recognition system demonstrates the level of value that an organisation places on individuals (Edvardsson, 2008). In leading KM endeavours, HRM functions should be implemented in such a way that they promote trust across an organisation (Oltra, 2005; Truss, Mankin, \& Kelliher, 2012) as well as willingness and opportunity to share knowledge (Sitlington, 2012). An organisational environment that is established on trust and desirable HRM functions, allows 
individuals to take an active role in the KM practices. Trust and fairness lie at the heart of $\mathrm{KM}$, and no transfer of tacit knowledge is viable within an organisation without trust and fairness (Thite, 2004). Furthermore, engaging individuals, developing talent and organisational design that encourage people to work together in sharing, acquiring, and developing knowledge (Baron, 2011) enable organisations to make positive use of their social capital.

Social capital refers to networks of relationships (Inkpen \& Tsang, 2005) that encourages organisations to establish connection enabling them to share knowledge and expertise. In addition, social capital is relationship based; thus it plays an important role in knowledge acquisition (Mu, Peng, \& Love, 2008). Research shows that organisations with a high level of social capital have a higher competency in KM practices than organisations with a low level of social capital (Hoffman, Hoelscher, \& Sherif, 2005). Therefore, organisations that aim to enhance their KM practices need to promote social interaction, and provide opportunities that encourage the flow of knowledge. Ivan and Eleni (2007) emphasise that there is no aspect where HRM and KM do not share commonalities. The literature reviewed here relating to HRM and KM generally suggests that HRM and KM go hand in hand and organisations that employ HRM strategies effectively can gain enhanced performance in their KM initiatives.

\subsection{Summary and Conclusion}

The review of literature suggests that SMEs employ a narrow range of KM processes. For instance, Fink and Ploder (2009b) contend that SMEs are characterised by four KM processes of knowledge: identification, acquisition, transfer and preservation. Some commentators (Fink \& Ploder, 2009b; Sivaramakrishnan et al., 2010) emphasise the use of IT for the KM processes, whilst others (Desouza \& Awazu, 2006; Wong \& Aspinwall, 2005) consider KM as a people centred effort in which IT only provides support. However, commentators (Desouza \& Awazu, 2006; Fink \& Ploder, 2009b) seem to agree that social processes are imperative in $\mathrm{KM}$ implementation. Furthermore, small businesses are characterised by informal KM processes (Hutchinson \& Quintas, 2008) and very few document their KM processes and activities. 
The review of literature suggests that $\mathrm{KM}$ in small businesses is still an underdeveloped area. Previous KM studies have focused on large organisations (Hutchinson \& Quintas, 2008; Wong \& Aspinwall, 2004). KM is an emerging field for SMEs and many are unsure of what it is and what it can do for their organisations (Wong \& Aspinwall, 2005). A set of CSFs helps SMEs in prioritising their KM activities (Wong \& Aspinwall, 2005). Wong and Aspinwall(2005) suggested that once the KM field has matured, future studies should target best practice SMEs to identify a set of CSFs for successfully implementing KM. This will help in exploring how KM processes of knowledge identification, acquisition, transfer, and preservation are enacted by SMEs. Targeting SMEs that have adopted CSFs in implementing KM helps provide a unified model on how they enact KM processes. This will enable other small businesses that have not considered $\mathrm{KM}$ as their business strategy to become more proactive in $\mathrm{KM}$ adoption by benchmarking against other small businesses' KM practices. Based on the latest empirical findings, it could be concluded that SMEs are in the early phase of implementing KM (Wei et al., 2011). Hence, more research is needed to address this gap in the literature by targeting knowledge-intensive small businesses. 


\section{CHAPTER 3: RESEARCH DESIGN AND METHODOLOGY}

The chapter begins by describing the research design used in the study. Next, the overview of the approach to data collection explains the sources of evidence and justifies the method employed in the present study. This is followed by an explanation and justification of sampling techniques employed. Pre-interview procedures and interview procedures explain the steps undertaken before and during interviews respectively. Next, the chapter explains the techniques employed in analysing data. Lastly, a description of strategies for dealing with ethical issues during the current study is outlined.

\subsection{Research Design}

There are two main research approaches which are known as ethnographic (qualitative) and scientific (quantitative) (Maylor \& Blackmon, 2005). Quantitative research method refers to a set of procedures aimed at developing and testing hypotheses, whereas qualitative research is concerned with meaning rather than measurement and investigates feelings, attitudes, perceptions, motivations, actions and interactions of individuals, groups and organisations (Maylor \& Blackmon, 2005). Other commentators have similar views on qualitative research, arguing that it places emphasis on unique features of a person, place, group, or a situation (Holmes, Dahan, \& Ashari, 2006) and exploring how people define, describe and interpret experiences (Vanderstoep \& Johnston, 2009). Qualitative research can be employed in exploratory studies before they are developed into extensive and complex studies (Hakim, 2000).

The present study used an exploratory design to investigate views of small business owners/managers on KM practices in the Western Australian small businesses. An exploratory design generally produces qualitative data (Zikmund, Babin, Carr, \& Griffin, 2010) which assisted the study to capture unique features of small businesses' KM practices. Furthermore, the use of exploratory design is often needed in developing research hypothesis (Zikmund et al., 2010) enabling the researcher to expand the breadth of KM investigation 
in Western Australian small businesses by employing a explanatory method in future. Nonetheless, the use of qualitative research and exploratory design in the present study provides a fundamental research foundation and direction regarding $\mathrm{KM}$ practices in Western Australian small businesses.

\subsection{Overview of the Approach to Data Collection}

The study used semi-structured interviews. The source of evidence on KM in small businesses was owners'/managers' views regarding KM adoption. Semistructured interviews involved prepared questioning guided by identified themes in a consistent and systematic manner (Berg \& Lune, 2012; Qu \& Dumay, 2011); however the researcher asked questions beyond interviewees' responses to the prepared questions (Bryman, 2008) to follow up on unexpected leads and lines of inquiry. The interviews were concentrated around the four KM processes of identifying, acquiring, sharing and storing knowledge and the extent to which the CSFs adoption assists small businesses with the processes of identifying, acquiring, sharing and storing knowledge.

The justification for using the interview method in the present study is essentially three-fold: First, interview is one of the most important data collection methods and is widely used in conducting field studies and ethnographic research (Qu \& Dumay, 2011). The use of the interview method was appropriate in the present study because it involved gathering qualitative data regarding the views of owners/managers on $\mathrm{KM}$ practices and the extent to which the adoption of the CSFs could assist small businesses in successfully implementing KM. Second, the interview method is a quick way to capture large amounts of data (Marshall \& Rossman, 1995). Due to limited time, budget and resources, the use of the interview method was appropriate for a student project within a limited time frame to gather data that could highlight the essence of $\mathrm{KM}$ practices in small businesses. Third, the interview method is a good way of learning about the world of others (Qu \& Dumay, 2011) enabling the researcher to understand people's everyday activities (Marshall \& Rossman, 1995). KM activities are daily functions of organisations, and therefore, the use of the interview method assisted the researcher to capture 
interesting viewpoints on KM practices enacted in small businesses as opposed to large businesses.

\subsection{Sampling}

The sampling technique used in this study was a combination of purposeful, snowball, and convenience sampling in which small businesses that are knowledge-intensive (e.g., consulting firms, law firms, IT firms, accounting firms) were selected in Western Australia. Purposive sampling (also known as judgemental sampling) (Hagan, 2006) involved the use of researcher's "knowledge or expertise about some group to select subjects who represent this population" (Berg \& Lune, 2012, p. 52). Purposive sampling was applied in the study by considering knowledge-intensive small businesses in the sample. Snowball sampling involved finding a case that led to a long list of cases (Swanborn, 2010) where the participants introduced the researcher to a list of other potential participants. The researcher then contacted the recommended organisations that were knowledge-intensive and invited them to participate in the study. Convenience sampling refers to ease of approach or accessibility (Berg \& Lune, 2012) to participants whereby the researcher selected eight small business organisations in Western Australia that were in close proximity of the researcher allowing access by personal and public transport.

The study targeted eight knowledge-intensive small businesses. When the potential organisations were identified, the researcher approached these organisations and invited them to participate in the study. Furthermore, Google search engine was also used to locate knowledge-intensive organisations in Metropolitan Perth. The researcher then contacted the organisations through telephone and briefly explained the background and purpose of the study to the person in charge of the organisation. In addition, the researcher e-mailed the research information letter (see Appendix I) to participants and requested them to read the information letter and e-mail the researcher if the participants wished to participate in the study. Upon their agreement to the conditions explained in the information letter, the researcher e-mailed and telephoned the 
participants to schedule a convenient time and place for the interview to be conducted.

\subsection{Pre-interview Procedures}

The initial step in recruiting participants involved making personal contacts with university colleagues and friends with the purpose of locating knowledgeintensive small businesses in Metropolitan Perth. Next, the researcher contacted the potential interview participants and e-mailed them the information letter containing the background to the study. The process of locating participants started by following up on the leads provided by university colleagues. This involved making personal approaches to one accounting firm and one IT firm in Metropolitan Perth. In addition, the researcher consulted the website of the Department of Commerce, Government of Western Australia and extracted a list of WA Industry and Export Awards winners. After identifying suitable organisations that were knowledge-intensive, the researcher contacted them through telephone and e-mail and invited them to participate in the study. Employing purposeful, snowball and convenience sampling approaches assisted the researcher to identify suitable interview participants that could meet the criteria of being knowledge-intensive.

\subsection{Interview Procedures}

The procedures of the interview as these occurred are reported as follows. A convenient venue and time for each participant and the researcher was discussed on the telephone or via e-mail. Prior to commencing each interview, an information letter highlighting the background and the purpose of the study was supplied along with a consent form prior to their participation. Each participant was requested to read the information letter (see appendix I) and consent form (see appendix II) carefully and then sign their agreement to the conditions. Upon agreement to the conditions, the researcher explained the key terms and phrases that were used during each interview. The interview began with the first set of questions containing 10 general demographic questions about owners/managers and their business (see Appendix III). Next, the main 
research questions (RQ1 \& 2) (see appendix IV)were asked with RQ1 containing four sub-questions and related prompting questions on the KM processes and RQ2 containing two sub-questions on the CSFs. Prompting and other relevant questions were asked throughout interviews. Each interview lasted between 45 to 60 minutes and was digitally recorded and transcribed. Subsequently a copy of each transcript was supplied to each participant to check for accuracy.

\subsection{Data Analysis}

Data analysis involves coding, categorising, concept mapping and theme generation (Simons, 2009), and examining, categorising, tabulating and reorganising (Yin, 2003) data. The study employed the data analysis method recommended by Miles and Huberman (1994). Other authors (Simons, 2009; Swanborn, 2010) also recommend the use of the data analysis procedures outlined in Miles and Huberman (1994). The process of analysing data started soon after the transcripts had been checked for accuracy by the researcher and the participant. Next, the researcher read and re-read the transcript and wrote reflective remarks on the margins of the transcripts. Thereafter, the researcher began employing the three data analytic procedures recommended by Miles and Huberman (1994). These are data reduction; data display; and conclusion drawing and verification.

First, data reduction involved selecting, focusing and abstracting key data (Simons, 2009) from the interview transcripts that related to the four processes of identifying, acquiring, sharing, and storing knowledge and the CSFs assisting small businesses in the KM processes. The data reduction process essentially involved the use of content analysis which assisted the researcher in "searching text for recurring words or themes" (Patton, 2002, p. 453). The researcher then highlighted the recurring words and themes surrounding the KM processes and the CSFs and wrote reflective remarks on the margins. The researcher used various colours such as green, blue, yellow, brown, and purple to colour code the data strips relating to identifying, acquiring, sharing, and storing processes and the CSFs. 
Second, data display involved using a matrix that allowed the researcher to observe what was happening, analyse information, draw conclusions or move to the next step of the analysis (Miles \& Huberman, 1994). According to Patton (1990), the purpose of classifying qualitative data is to facilitate the search for themes, within a particular setting, or across cases. In this study, to facilitate cross-interview analysis, data was displayed through building matrices with a descriptive intent (Miles \& Huberman, 1994).Rows were devoted to the numbers assigned to interview participants (1-8), and columns to either phases of the knowledge management process the CSFs in KM. Cell entries in the matrices consisted of direct quotes taken from coded data segments located in the interview transcripts.

Third, conclusion drawing and verification was the process where patterns, propositions and explanations were accepted and approved (Simons, 2009). This involved reviewing the recurring words and common themes in the matrix to ensure that the analysis was enacted accurately. Once the researcher was convinced, the common KM themes and patterns were confirmed and reported as the overall findings of the study.

\subsection{Strategies for Dealing with Ethical Issues}

The fundamental principle in ethical research is 'to do no harm' (Simons, 2009) to respondents. This was ensured by following the guidelines on research procedures and conduct set by the Edith Cowan University's Human Research Ethics Committee. The researcher sought assistance from the supervisors regarding any ethical issues during the course of the study.

The study involved an informed consent meaning that all participants participated with intent (Berg \& Lune, 2012). Small business owner/manager participants were contacted through e-mail, mail, telephone or in-person visits to seek their voluntary participation in the research. An information letter highlighting the background and the purpose of the study was supplied to all participants along with a consent form containing "potential risks and benefits" (Berg \& Lune, 2012, p. 90) of the study prior to their participation. Each participant was requested to read the information letter and consent form 
carefully and then sign their agreement to the conditions. All interviews were recorded digitally, transcribed with the help of a dictator pen, and a copy of the digital transcript of the interview was supplied to each respondent so that they had an opportunity to check it for accuracy and make amendments as appropriate.

Confidentiality and anonymity was maintained strictly as set by the university's ethics committee. Interview recordings, transcripts and data analysis are kept confidential on the researcher's home personal computer, restricted with a secure password. No name or identifying details of participants and their organisations are revealed to ensure confidentiality. To protect the privacy of participants and their organisations, no names or any identifying details are disclosed in this report.

\subsection{Summary}

The chapter provided a basic overview of the methodology employed in the present study. Using an exploratory design, data was collected through semistructured face-to-face interviews. The sampling techniques employed in the study are a combination of purposeful, snowball, and convenience sampling. Interviews were conducted with eight owners/mangers of knowledge-intensive small businesses in Metropolitan Perth. The pre-interview procedures involved making initial contacts with university colleagues and friends for the purpose of locating interview participants in the knowledge-intensive small businesses in Metropolitan Perth. Potential interview participants were contacted and a copy of the information letter was e-mailed to them. The interview procedures involved making arrangement with interview participants regarding a convenient time and place for interviews to be conducted. Prior to each interview, a copy of the information letter and a consent form were supplied to the interview participants. Upon agreement to conditions, the interview participants were asked to sign to the conditions. Data were analysed using the method by Miles and Huberman (1994) and these are data reduction; data display; and conclusion drawing and verification. The study was conducted by following the research procedures and conduct set by the Edith Cowan University's Human 
Research Ethics Committee. Where ethical issues arose, the researcher sought assistance from research supervisors. 


\section{CHAPTER FOUR: FINDINGS OF THE INTERVIEWS}

The chapter presents findings of the interviews relating to knowledge management (KM) processes (i.e., identifying, acquiring, sharing, and storing) and factors that assist small businesses in their KM endeavours in eight selected Western Australian small businesses. The chapter begins with a profile of participants and their firms, followed by the presentation of findings relating to KM processes. Next, the chapter presents the findings relating to factors that foster KM in small businesses.

\subsection{Profile of Participants and their Firms}

Table 4.1 provides a profile of the participants and their firms.

Table 4.1 Profile of the participants and their firms

\begin{tabular}{|c|c|c|c|c|c|}
\hline$\#$ & Job title & Qualification & Services & $\begin{array}{l}\text { Organisation } \\
\text { size }\end{array}$ & $\begin{array}{l}\text { Duration of } \\
\text { service }\end{array}$ \\
\hline P 1 & $\begin{array}{l}\text { Director-Technical } \\
\text { Manager }\end{array}$ & Year 12 & IT network solutions & 5 employees & 27 years \\
\hline P 2 & $\begin{array}{l}\text { Consultant- } \\
\text { Recruitment } \\
\text { Specialist }\end{array}$ & $\begin{array}{l}\text { Master's in Industry } \\
\text { Psychology }\end{array}$ & $\begin{array}{l}\text { Recruitment and } \\
\text { consulting services }\end{array}$ & 18 employees & 2 months \\
\hline P 3 & Director- Lawyer & Honours & $\begin{array}{l}\text { Planning and } \\
\text { Environmental Law } \\
\text { services }\end{array}$ & 2 employees & 13 years \\
\hline P 4 & $\begin{array}{l}\text { Director- } \\
\text { Accountant }\end{array}$ & $\begin{array}{l}\text { Bachelor of } \\
\text { Commerce }\end{array}$ & $\begin{array}{l}\text { Tax consulting services, } \\
\text { accounts preparation for } \\
\text { small businesses, } \\
\text { corporate secretarial } \\
\text { services, and general } \\
\text { business advice }\end{array}$ & 8 employees & 19 Years \\
\hline P 5 & $\begin{array}{l}\text { Director- Chief } \\
\text { Executive Officer }\end{array}$ & $\begin{array}{l}\text { Bachelor of } \\
\text { Commerce }\end{array}$ & $\begin{array}{l}\text { Real estate services } \\
\text { (property management, } \\
\text { project marketing, } \\
\text { general sales) }\end{array}$ & 22 employees & 46 years \\
\hline P 6 & Property Manager & Year 12 & Property rental services & 9 employees & 4 months \\
\hline P 7 & $\begin{array}{l}\text { Marketing and } \\
\text { Communications }\end{array}$ & $\begin{array}{l}\text { Bachelor of } \\
\text { Communications }\end{array}$ & $\begin{array}{l}\text { Accounting and business } \\
\text { advisory services }\end{array}$ & 24 employees & 2 years \\
\hline P 8 & CEO & $\begin{array}{l}\text { Master's in } \\
\text { Management \& } \\
\text { Engineering } \\
\end{array}$ & $\begin{array}{l}\text { Consultancy services in } \\
\text { Engineering industry (i.e., } \\
\text { oil and gas) }\end{array}$ & 6 employees & 7 years \\
\hline
\end{tabular}

A total of eight face-to-face interviews were conducted with managers and directors of knowledge-intensive small businesses in Western Australia. Out of 
the eight participants, only one participant was female, the rest were male. Five of the eight participants ( $P 1,3,4,5,8)$ were the directors of the firms and the rest $(P 2,6,7)$ were managers in their fields. The qualification of participants ranged from Year $12(P 1,6)$, Bachelor degrees ( $P$ 4, 5, 7), Honours ( $P$ ), to Master degrees (P 2,8). The majority of the participants were well-qualified and demonstrated a high level of KM awareness. The duration of participants' involvement in their organisations ranged from two months $(P 2)$ to 46 years $(P$ 5). The in-depth experience of a majority of the participants in their firms and industries was evident in their substantial knowledge and experience relating to $\mathrm{KM}$ that they shared during the interviews. The participants reported the delivery of the following services in their firms: IT solutions $(P 1)$, consulting $(P$ $2,3,8)$, real estate $(P 5,6)$, and accounting $(P 4,7)$. The number of employees employed in the organisations ranged from two staff including the director of one of the organisations ( $P$ 2), and 24 employees ( $P$ 7) as shown in Table 4.1. The initial decision was to recruit participants that employ 20 or fewer employees. However, the reader will note that there are two firms (i.e., P 5, P 7) with marginally more than 20 employees. The number of employees employed by the participants included casual, part-time and full-time employees. Some of the participants also included contractors on their employee list.

\subsection{KM Processes}

The interviews regarding $\mathrm{KM}$ processes sought to explore how knowledgeintensive small businesses identify, acquire, share and store knowledge. Findings in relation to each of these processes are presented below.

\subsubsection{Identifying Processes}

Table 4.2 shows the wide range of sources that small businesses in the study drew on to obtain knowledge.

Findings of the study suggest that the key sources that the knowledge-intensive small businesses use to gather their knowledge, depends on the industries in which they operate. 
Table 4.2 Identifying sources of knowledge

\begin{tabular}{|c|c|c|c|c|}
\hline$\#$ & Industry & & Sources of knowledge & \\
\hline P 1 & IT & $\begin{array}{l}\text { Suppliers } \\
\text { Trade magazines }\end{array}$ & $\begin{array}{l}\text { Internet } \\
\text { Tutorial learning materials }\end{array}$ & \\
\hline P 2 & Consulting & $\begin{array}{l}\text { Sales staff } \\
\text { Personal networks } \\
\text { CEO }\end{array}$ & $\begin{array}{l}\text { Friends } \\
\text { Journals } \\
\text { Initia software } \\
\text { Staff }\end{array}$ & $\begin{array}{l}\text { Periodic } \\
\text { University } \\
\text { Research }\end{array}$ \\
\hline P 3 & Law & $\begin{array}{l}\text { Research } \\
\text { Internet } \\
\text { Courts' websites } \\
\text { Tribunals }\end{array}$ & $\begin{array}{l}\text { Publishers } \\
\text { Lawyers }\end{array}$ & $\begin{array}{l}\text { Colleagues } \\
\text { Town planning } \\
\text { consultants }\end{array}$ \\
\hline P 4 & Accounting & $\begin{array}{l}\text { Australian Taxation } \\
\text { Office (ATO) website } \\
\text { State Government } \\
\text { websites } \\
\text { Tax training seminars }\end{array}$ & $\begin{array}{l}\text { Colleagues } \\
\text { Accountants } \\
\text { Business associates } \\
\text { Tax Institute } \\
\text { CCH and Tax Institute products }\end{array}$ & $\begin{array}{l}\text { Professional bodies } \\
\text { Social functions } \\
\text { Master Tax Guide }\end{array}$ \\
\hline P5 & Real estate & $\begin{array}{l}\text { Real estate Institute } \\
\text { Urban Developer's } \\
\text { Institute } \\
\text { Online magazines } \\
\text { Property Developers' } \\
\text { Association }\end{array}$ & $\begin{array}{l}\text { Best Practice } \\
\text { Macquarie Bank } \\
\text { Accountants } \\
\text { Solicitors }\end{array}$ & $\begin{array}{l}\text { Family-friends } \\
\text { In the Black magazine } \\
\text { Customers } \\
\text { Competitors }\end{array}$ \\
\hline P 6 & Real estate & Website & Seminars & \\
\hline P 7 & Accounting & $\begin{array}{l}\text { Institute of Chartered } \\
\text { Accountant } \\
\text { The Taxation Institute }\end{array}$ & $\begin{array}{l}\text { Australian Taxation Office } \\
\text { (ATO) }\end{array}$ & $\begin{array}{l}\text { External training } \\
\text { sessions } \\
\text { Business networking } \\
\text { events }\end{array}$ \\
\hline P 8 & $\begin{array}{l}\text { Training } \\
\text { provider }\end{array}$ & $\begin{array}{l}\text { Federal Government } \\
\text { WA Department of } \\
\text { Training } \\
\text { Industry Skills Council }\end{array}$ & $\begin{array}{l}\text { Internet } \\
\text { Unions } \\
\text { Word of mouth } \\
\text { Competitors }\end{array}$ & $\begin{array}{l}\text { Experience } \\
\text { Business networks } \\
\text { Partnership and alliance } \\
\text { with other organisations }\end{array}$ \\
\hline
\end{tabular}

There appears to be no one preferred source that the firms in the findings draw on to obtain knowledge. However, the most common source seems to be the internet. The use of the internet was primarily justified to be efficient and easy to access. As a lawyer from a law firm remarked:

The online resources are invaluable. It's all about identifying what to look for and knowing where to look for it.

As shown in the table, a majority of the participants $(P 1,4,5,7,8)$ noted that their firms have membership with professional bodies and associations or subscribe to publications to gather their required knowledge. Although small businesses tend to rely on their professional bodies to obtain knowledge, the 
use of the internet is the primary source of knowledge. This is mainly due to the fact that small businesses are time poor. Therefore, the use of the internet is seen as an efficient and effective method of acquiring knowledge for small businesses.

Another important source of knowledge is customers. To ensure customers receive the right service, the CEO of a real estate firm noted that the organisation conducts customer surveys to gain feedback regarding the quality of its customer service, the mode of the service, and whether customers have any recommendations or comments that need to be considered.

\subsubsection{Acquiring Processes}

Table 4.3 presents the findings relating to the knowledge topics that firms in the sample acquire. The processes of identifying and acquiring knowledge seemed to be conceived as a single process by the participants during the interviews. Therefore, to avoid confusion, the researcher asked the participants to highlight the knowledge topics that they acquire in the acquiring processes.

Table 4.3 Acquiring processes

\begin{tabular}{|c|c|c|c|c|}
\hline \# & Industry & & Knowledge topi & \\
\hline P 1 & IT & $\begin{array}{l}\text { Updates in } \\
\text { technology }\end{array}$ & $\begin{array}{l}\text { Network solution to small } \\
\text { businesses }\end{array}$ & $\begin{array}{l}\text { Computer } \\
\text { Hardware/software }\end{array}$ \\
\hline P 2 & Consulting & $\begin{array}{l}\text { Information on } \\
\text { legislation changes } \\
\text { Succession planning }\end{array}$ & $\begin{array}{l}\text { Policies } \\
\text { Occupational health and } \\
\text { safety awareness } \\
\text { Changes in billing rates }\end{array}$ & $\begin{array}{l}\text { Tricks and tips } \\
\text { Opportunity to new } \\
\text { business } \\
\text { Information about } \\
\text { competitors }\end{array}$ \\
\hline P 3 & Law & $\begin{array}{l}\text { Court matters } \\
\text { Statutory materials }\end{array}$ & Legislation & $\begin{array}{l}\text { Precedents } \\
\text { Law and processes }\end{array}$ \\
\hline P 4 & Accounting & $\begin{array}{l}\text { Tax developments } \\
\text { Practice } \\
\text { management }\end{array}$ & $\begin{array}{l}\text { Market rates } \\
\text { Working hours }\end{array}$ & $\begin{array}{l}\text { The type of staff } \\
\text { Financial affairs }\end{array}$ \\
\hline P5 & Real estate & $\begin{array}{l}\text { Professional } \\
\text { development } \\
\text { Property } \\
\text { management }\end{array}$ & $\begin{array}{l}\text { Mandatory courses to } \\
\text { maintain licence } \\
\text { Benchmarking } \\
\text { Law }\end{array}$ & $\begin{array}{l}\text { Superannuation } \\
\text { Succession planning } \\
\text { Customer feedback }\end{array}$ \\
\hline P 6 & Real estate & $\begin{array}{l}\text { Property value } \\
\text { Tenant reference } \\
\text { check }\end{array}$ & Credit check & Changes in legislation \\
\hline P 7 & Accounting & Tax updates & Process improvement & \\
\hline P 8 & $\begin{array}{l}\text { Training } \\
\text { provider }\end{array}$ & $\begin{array}{l}\text { Syllabus } \\
\text { Standard }\end{array}$ & Contracts & $\begin{array}{l}\text { Student development } \\
\text { resources }\end{array}$ \\
\hline
\end{tabular}


As shown in Table 4.3, the knowledge topics that knowledge-intensive small businesses acquire are reflective of their industry needs. An extensive amount of obtained knowledge in the sample businesses is for operational needs. For instance, law firms and accounting firms must acquire technical updates and developments in legislations which affect their day-to-day business activities and processes. However, managers in some organisations think strategically. For instance, a consultant (P 2) referred to acquiring 'tricks and tips' on how to excel in business, exploring opportunities for new business and gaining knowledge about competitors. The intention behind this initiative is to keep the organisation ahead of the competition.

In order to thrive in business, it is necessary that businesses develop relationships and networks. For instance, the Communication and Marketing Manager in an accounting firm claimed:

We regularly participate in networking events. Basically, we just aim to establish contact and build relationship with other service providers (e.g., lawyers).

Building relationships with other organisations was seen as necessary to thrive in business. Building relationships and networks creates social capital which has the potential to give businesses a sustained competitive advantage. In regard to establishing relationships, the Communication and Marketing Manager remarked:

A lot of it comes down to personality. Basically, in order to establish relationship, it's about taking an interest in individuals and talking about things that interest them. And then if it goes any further, I then think it's important to have the knowledge behind it.

\subsubsection{Sharing Processes}

There is a wide range of methods that can be employed for sharing knowledge. As shown in Table 4.4, the most common methods of sharing knowledge inside 
the organisations studied are meetings and face-to-face conversations. Communication with customers in knowledge-intensive organisations is primarily done through e-mail. The methods of sharing knowledge inside organisations studied were largely informal. Being small in size and number, small businesses have the benefit of sharing knowledge more effectively and efficiently than large organisations. One method of sharing knowledge that was discussed in the interviews was mentoring. The Communication and Marketing Manager of an accounting firm remarked:

I do think mentoring is something that people get a lot out of, even if it isn't for work. Even if it's how they conduct themselves in the office and how they answer the phone.

Table 4.4 Sharing processes

\begin{tabular}{|c|c|c|c|c|}
\hline \# & Industry & \multicolumn{3}{|c|}{ Methods of sharing knowledge } \\
\hline P 1 & IT & $\begin{array}{l}\text { Word of mouth } \\
\text { Meeting }\end{array}$ & $\begin{array}{l}\text { E-mail } \\
\text { Physically showing people }\end{array}$ & \\
\hline P 2 & Consulting & $\begin{array}{l}\text { E-mail } \\
\text { SMS } \\
\text { Database } \\
\text { Initia software }\end{array}$ & $\begin{array}{l}\text { O Drive } \\
\text { Showing by example } \\
\text { Face-to-face meetings } \\
\text { Repeating } \\
\text { Videos }\end{array}$ & $\begin{array}{l}\text { E-learning modules } \\
\text { Presentation } \\
\text { Computer demonstration } \\
\text { Copying } \\
\text { Informal social interactions }\end{array}$ \\
\hline P 3 & Law & E-mail & Face-to-face meetings & Electronic letters \\
\hline P 4 & Accounting & Meetings & E-mail & Informal conversations \\
\hline P5 & Real estate & $\begin{array}{l}\text { Showing by } \\
\text { example } \\
\text { (mentoring) }\end{array}$ & $\begin{array}{l}\text { E-mail } \\
\text { Memo }\end{array}$ & $\begin{array}{l}\text { Meetings } \\
\text { Presentations }\end{array}$ \\
\hline P 6 & Real estate & $\begin{array}{l}\text { Word of mouth } \\
\text { E-mail }\end{array}$ & $\begin{array}{l}\text { Writing notes and sticking it on } \\
\text { monitor }\end{array}$ & Telephone \\
\hline P 7 & Accounting & $\begin{array}{l}\text { E-mail } \\
\text { Face-to- face } \\
\text { meetings }\end{array}$ & $\begin{array}{l}\text { Showing by example } \\
\text { Conversations } \\
\text { Presentation }\end{array}$ & $\begin{array}{l}\text { Report } \\
\text { Memos } \\
\text { Mentoring }\end{array}$ \\
\hline P 8 & $\begin{array}{l}\text { Training } \\
\text { provider }\end{array}$ & $\begin{array}{l}\text { Formal and } \\
\text { informal meetings }\end{array}$ & $\begin{array}{l}\text { E-mail } \\
\text { Telephone }\end{array}$ & $\begin{array}{l}\text { Website } \\
\text { LogMeln Hamachi } \\
\text { E-learning }\end{array}$ \\
\hline
\end{tabular}

Conversely, the CEO of a real estate expressed a different viewpoint on mentoring:

Mentoring is effective, but the danger is, if that person leaves, then you gotta start all over again, mentoring someone else. I think it isn't satisfactory and it's time consuming. 


\subsubsection{Storing Processes}

Findings of the interviews suggest that knowledge-intensive small businesses use various methods of storing knowledge. Table 4.5 highlights the various methods that the sample small businesses used to store their knowledge.

Table 4.5 Storing processes

\begin{tabular}{|c|c|c|c|}
\hline$\#$ & Industry & \multicolumn{2}{|c|}{ Methods of storing knowledge } \\
\hline P 1 & IT & $\begin{array}{l}\text { Servers } \\
\text { Databases }\end{array}$ & Customised databases \\
\hline P 2 & Consulting & $\begin{array}{l}\text { Books } \\
\text { E-mail }\end{array}$ & $\begin{array}{l}\text { Database } \\
\text { Paper form }\end{array}$ \\
\hline P 3 & Law & $\begin{array}{l}\text { File processor software } \\
\text { Server } \\
\text { Save on computer } \\
\text { Folders }\end{array}$ & $\begin{array}{l}\text { Microsoft Office } \\
\text { Practice management system } \\
\text { Store in the head }\end{array}$ \\
\hline P 4 & Accounting & $\begin{array}{l}\text { User manual } \\
\text { MYOB } \\
\text { ICQ }\end{array}$ & $\begin{array}{l}\text { Files } \\
\text { E-mail } \\
\text { Server }\end{array}$ \\
\hline P5 & Real estate & $\begin{array}{l}\text { Procedure manual } \\
\text { Computer } \\
\text { Checklist } \\
\text { Corporate governance document }\end{array}$ & $\begin{array}{l}\text { Succession plan document } \\
\text { Company code of ethics document } \\
\text { Code of ethics for employees document }\end{array}$ \\
\hline P 6 & Real estate & $\begin{array}{l}\text { Store in the mind } \\
\text { Hard copies } \\
\text { Software }\end{array}$ & $\begin{array}{l}\text { E-mail } \\
\text { Computer storage }\end{array}$ \\
\hline P 7 & Accounting & $\begin{array}{l}\text { Procedure manual } \\
\text { Network server }\end{array}$ & $\begin{array}{l}\text { Spread sheets } \\
\text { APS }\end{array}$ \\
\hline P 8 & $\begin{array}{l}\text { Training } \\
\text { Provider }\end{array}$ & $\begin{array}{l}\text { AVETMISS software } \\
\text { PDF files on computer }\end{array}$ & Database \\
\hline
\end{tabular}

As shown in the table, the most common method of storing knowledge is the adoption of software (e.g., document management software). The findings also reveal that generally, knowledge-intensive small businesses document their knowledge. There is a high degree of technology adoption in storing knowledge, as opposed to storing knowledge in paper files and documents.

An important function of storing knowledge involves protecting knowledge. For example, the CEO of a real estate firm claimed: 
It's important to classify knowledge from highly confidential to freely available. You can assign passwords to protect your knowledge, but you can never protect knowledge 100 per cent. It's business. You gotta take risks.

The findings suggest that the degree of storing knowledge varies from organisation to organisation. Some organisations are highly protective, whereas others are willing to share knowledge with their competitors. For example, the CEO of a real estate firm remarked:

It's a role of management to keep innovating and keeping a step ahead from competitors. I have found that some times by sharing knowledge with a competitor, I move a step forward, because I have given it away.

Furthermore, the participant expressed his concern regarding a potential knowledge loss when he exits the organisation:

A large portion of my knowledge is stored in my head. I have gathered various materials over the past years that might help the business in future. I want them to be stored in a categorised manner, either topic wise, subject wise, or alphabetically.

Overall the findings suggest that the primary method of storing knowledge is technology-based. The CEO of a training provider claimed that:

We don't keep any hard copies. We use the specific software and all the information is stored on our system.

However, it was acknowledged during the interview that people take away an extensive amount of knowledge when they leave the organisation. The consultant further remarked that:

With regard to knowledge leaving the organisation, I can imagine, when a manager leaves, you do lose a lot because so much is gained through 
experience. I think friendship is probably one of the critical things that you lose. And friendship is one of those things that enable the transfer of knowledge.

\subsection{Factors Fostering KM Processes}

In the interviews, participants were asked to express their views about factors that foster KM in their organisations. The researcher used the framework of Wong and Aspinwall (2005) during the interviews. Participants in the sample were asked to express their views on the importance of the 11 factors outlined by Wong and Aspinwall (see appendix IV). The highest perceived importance was attributed to culture, strategies and purpose, resources, training and education, information technology, and motivational aids. Findings in relation to each of these factors are presented below.

\subsubsection{Culture}

During the interview, participants were asked to highlight the most important factor that fosters $\mathrm{KM}$. It was noted that participants placed the highest emphasis on culture among all other factors assisting small businesses in the $\mathrm{KM}$ processes. One of the participants claimed that culture is intangible, and it facilitates the flow of knowledge. Furthermore, participants were asked to comment on the type of culture that facilitates knowledge sharing. One of the participants remarked:

An open - friendly culture where you still have strict rules on conduct, on work ethic, and on how you treat a client. Having that kind of set culture, lets you know what you exactly can and can't do in the office (Communication and Marketing Manager, accounting firm).

A culture that valued openness was also seen an important factor in enhancing employee morale. For example a consultant from a consulting firm remarked: 
If you are having a bad day, everyone here should know about it because it can be a source of humour. If you hide it, you might develop a strategy of coping that involves muttering under breaths or storming off outside... and they are not gonna go well because people are gonna wonder what you are doing.

The relevance of openness as a cultural value to KM was because of its capacity to encourage employees to voice their concerns with management, give feedback, and accordingly seek management assistance.

In seeking to explore the importance of an open culture, the Property Manager of a real estate firm claimed:

We develop a closer bond. For example talking about things like how the weekend went. By this way, we learn about our colleagues' morale and know their interests. Organisations that don't have these, you don't know who you are working with.

\subsubsection{Strategies and Purpose}

Participants were asked to express their views on KM strategies. The findings reveal that small businesses do not generally have a written policy on $\mathrm{KM}$. Strategy was perceived as an important factor in KM as the CEO of a real estate firm remarked:

I think having a clear strategy, vision and purpose can straight away clear up as to why people are here.

The strategy of small businesses is mainly engrained and embedded in their daily activities. For instance, a consultant from a consulting firm claimed that:

We are specific in our strategy and purpose and that is to enhance our ability to service our customers. At the moment, we are considering the 
bringing in of new technologies that will enable us to instantly convey knowledge to clients.

Most participants explained their strategies and purpose in regard to adopting a new technology to enhance communication. The adoption of new technology was considered to assist small businesses in leveraging knowledge more effectively. For instance, the CEO of a real estate firm and the Marketing and Communications Manager of an accounting firm had considered going on iCloud. The CEO of the real estate firm further claimed that adopting new technology (i.e., iCloud) that enhances communication is seen as a pro-active strategy in sharing knowledge.

\subsubsection{Resources}

During the interview, participants were asked to express their views on the importance of resources to KM. The perceived importance of resources was that resources facilitate KM practices in organisations. The Director of an IT firm emphasised that generally, people do not like working in a company that has limited stock or resources. Similarly, the director of an accounting firm claimed that:

If you don't provide your staff with the space, technical resources, workstation, and things that they need through their job, then they are not gonna be efficient.

As knowledge-intensive small businesses heavily rely on technical resources (e.g., computer, high speed IT network) a lack of resources may slow the work processes. Ordinary resources such as good printers, scanners, and so on were also considered to influence the performance of employees in dealing with explicit knowledge (e.g., reviewing and developing organisational policies). However, another participant - the Communication and Marketing Manager of an accounting firm expanded the view of organisational resources. She claimed that: 
We have the ability to tap into the network resources if we don't have that knowledge. I think if you don't have that ability, you are limited in your growth for business. If you wanna constantly increase your business, you gotta be going out and searching for work.

It is worthwhile to consider personal contacts and networks as key resources. However, as evident from the views of the participants, the level of personal relationships depends on the organisation's capacity and networking skills. It is interesting to note that knowledge-intensive small businesses do not merely consider resources in the forms of land, labour and capital alone, but also recognise its importance in an intangible form (e.g., relationships and networks with other organisations).

\subsubsection{Training and Education}

Findings suggest that a key strategy of acquiring and sharing knowledge for knowledge-intensive organisations is training and education. Whilst, employees learn via on the job training and induction, employees are also encouraged to participate in externally-provided professional training. In exploring the interest of small businesses in sending their staff to external training, the Communication and Marketing Manager of an accounting firm remarked:

We encourage our staff to do courses and consider them as incentives to actually further their education.

Similarly, another participant claimed:

Training and education is a key driver of our success because we provide technical information on the income tax assessments (Director, accounting firm).

In seeking to explore whether participants or their staff members had attended any training seminars on $\mathrm{KM}$, it was noted that neither study participants nor their staff members had attended any workshops on KM and participants had 
also not heard if any KM training was existent. Nevertheless, some participants were keen to attend $\mathrm{KM}$ workshops and training to gain awareness on $\mathrm{KM}$ practices.

\subsubsection{Information Technology}

Information technology (IT) was considered among the most important factors in KM practices. For example, a consultant from a consulting firm remarked:

One of the biggest parts of organisational infrastructure is software. It is the main part of our daily activities.

Generally, the internet was seen as one of the most common methods of acquiring knowledge. Furthermore, the use of software and data management software was seen a common practice in knowledge-intensive organisations. The CEO of a real estate firm and the Communication and Marketing Manager of an accounting firm expressed their interest in joining the iCloud environment. The CEO of a training provider asserted that the use of software (i.e., AVETMISS) is a mandatory requirement. AVETMISS is a student data management system that facilitates transparency for legal purposes and fulfils the federal and state government reporting requirements for registered training organisations (RTO). The CEO of the training provider regarded information technology as the second most important factor in $\mathrm{KM}$.

\subsubsection{Motivational Aids}

During the interview, participants were asked to express their views on factors that encourage individuals to engage in $\mathrm{KM}$. In seeking to explore the importance of motivational aids, it was noted that there is no single factor that promotes knowledge sharing. For example, the director of an accounting firm remarked that:

What motivates one person may not motivate another. For some, it could be monetary, for others, it could be flexibility. 
Conversely, the Property Manager of a real estate placed a high emphasis on monetary incentives and remarked that:

Money is number one factor because it buys you holidays, dinner, cars, anything you name it. Money helps you get time off work and relax.

Money gives you flexibility. Whether we like it or not, money dictates.

Generally speaking, participants believed that money is an important factor in motivating people, but the majority of them acknowledged that money is not necessarily the most important factor in promoting $\mathrm{KM}$. One participant asserted that if organisations reward employees with satisfactory level of monetary incentives, generally, other factors such as recognition, respect, meaning, and flexibility can have a strong impact on employee morale and performance. One of the participants remarked:

Having someone to say 'you have done a really good job' is effective. It encourages you do a good job next time. It encourages you to keep that standard of work. Because you know that someone has noticed. Even if it's a pat on the back. If someone attended a training seminar, everyone would thank them at the end of training. I know it's minimal, but if they didn't' get the thank you, they wouldn't wanna do it next time. I know if I have done something, and it has been hard, my boss knows that it was a hard job, just having them acknowledge by saying, 'thank you for trying', it will work.

Certainly, getting people to share their knowledge and invest their time in $\mathrm{KM}$ practices, involves instantaneous and consistent encouragement. It is necessary that organisations recognise the value of motivation and implement strategies that foster valuing people.

\subsubsection{Other Factors}

Although the interview participants believed that the other CSFs were important, they were not able to elaborate on them in the context of their own 
firms during the interviews. These CSFs are: management leadership and support, KM processes and activities, organisational infrastructure, HRM, and measurement. It is surprising to notice that few participants recognised the importance of $\mathrm{HRM}$ in $\mathrm{KM}$ processes. This may be because participants considered HRM as a separate organisational department which is typically non-existent in small businesses. In addition, there is a flaw in the framework of Wong and Aspinwall (2005) in that it has separated HRM from other factors that are closely tied to people management in organisations (e.g., culture, strategies and purpose, training and education, motivational aids). That is probably why, during the interviews, participants did not reflect on the importance of HRM in an organisation's KM endeavours.

\subsection{Summary}

A majority of participants in the sample demonstrated a high level of understanding and knowledge regarding KM practices. Generally, the KM processes reported by the participants, reflected their industry needs. Findings suggest that the most common source of knowledge is internet. The type of knowledge, knowledge-intensive small businesses gather, primarily relates to their operational needs and this involves gathering technical updates and developments in legislation. Common methods of sharing knowledge within the industry and storing knowledge are the internet and software respectively. However, the most common method of sharing knowledge internally is face-toface meetings.

The highest importance was attributed to culture. Strategies, resources, training and education, information technology, and motivational aids also received significant attention during the interviews. Other factors that participants considered important but could not elaborate on in the context of their own firms during the interviews were: management leadership and support, KM processes and activities, organisational infrastructure, HRM, and measurement. 


\section{CHAPTER 5: DISCUSSION}

The discussion of the findings of this study is structured according to the research questions:

1. How do the selected Western Australian small businesses identify, acquire, share and store knowledge?

2. What effects, if any, does the extent of critical success factors (CSFs) adoption have on the processes of identifying, acquiring, sharing and storing knowledge?

The chapter starts by discussing the findings in relation to research question 1. Specifically, the discussion embeds the findings relating to how knowledgeintensive small businesses identify, acquire, share and store knowledge in the existing literature on $\mathrm{KM}$ processes. Next, the chapter discusses the findings in relation to research question 2, which focuses on the factors that foster KM processes, and makes links to the relevant literature.

\subsection{KM Processes}

Overall, the findings suggest that $\mathrm{KM}$ processes (i.e., identifying, acquiring, sharing and storing) have been moderately implemented by knowledgeintensive small businesses. The nature and extent of $\mathrm{KM}$ adoption is primarily reflective of industry needs. Findings in relation to each of the four KM processes are discussed below.

\subsubsection{Identifying Processes}

The identification of external knowledge involves analysing and describing an organisation's knowledge environment (Probst et al., 2002). The findings suggest that the key source of knowledge for knowledge-intensive small businesses is the internet. The internet being the fastest growing technology among other technologies (Alam, 2009) has changed the way businesses operate. Most participants described the benefits of online resources as being affordable and easy to access. This suggests that small businesses that effectively use the internet do not necessarily need to physically attend a workshop or seminar in order to obtain knowledge. 
The sources of online resources for knowledge-intensive small businesses are mainly the respective professional bodies and the Australian federal and state government websites. This is due to the trustworthiness, usefulness and relevance of the information that is accessible on the respective websites of the professional bodies and government departments. Using the respective websites of the professional bodies and various government departments assists knowledge-intensive small business to keep abreast with developments in their professional fields and with changes to legislation. Keeping up-to-date with the developments in the respective professional fields and changes to legislation is considered a critical factor in business survival.

In terms of strategically developing the business, having knowledge about customers was viewed as an important factor in enhancing business performance. Customer knowledge refers to knowledge about customers, for customers and contained by customers (Qiu \& Xu, 2011). Customer knowledge can be identified through assessing customer demands, experience, preferences, and insight (Qiu \& Xu, 2011). Some of the participants mentioned the use of customer surveys to assess the quality of their products or services. Gaining customer feedback is an effective method to identify the level of customer satisfaction with customer service. This allows small businesses to identify their strengths and allocate their resources to areas that need further improvement (e.g., meeting the emerging demands of customers). Addressing the varying needs of customers allows small businesses to keep pace with the market competition.

\subsubsection{Acquiring Processes}

Findings suggest that the types of knowledge, knowledge-intensive small businesses acquire, generally relate to both technical updating in their respective professional fields and developments in legislation. This is mainly reflective of industry and operational needs. Knowledge-intensive small businesses have affiliations with professional bodies, and subscribe to relevant industry magazines to gain updates. Affiliation with the respective professional bodies and subscriptions with relevant industry magazines assist knowledge- 
intensive small businesses in obtaining relevant industry knowledge that drives their day-to-day operations.

From a strategic human resource management perspective, some of the participants perceived gaining a sustained competitive advantage through acquiring 'tricks and tips' and developing networks and relationships. These can be viewed in the context of developing social capital. Social capital is a network of social relationships that can assist individuals in developing and applying knowledge (Mohr, Young, \& Burgess, 2012). The key feature of social capital is to create a 'good will' among individuals (Adler \& Kwon, 2002) and this can take the form of developing casual acquaintance to close familial ties (Harris, Rae, \& Misner, 2012). As pointed out in the literature, organisations with a high level of competency in social capital perform better in $\mathrm{KM}$ practices than those organisations that lack social capital (Mu et al., 2008). This is specifically imperative to small businesses due to resource constraints. Establishing social networks within and outside small business organisations has the potential to assist small businesses in locating more sources of knowledge relating to customers and competitors. Furthermore, a strong social relationship is a valuable source of new knowledge (Lowik, Rossum, Kraaijenbrink, \& Groen, 2012).

The relationship of a small business through social networks is largely based on trust, and the type of knowledge that is transferred is more realistic and reliable than knowledge acquired through the internet and other publications. Individuals tend to share tacit knowledge and provide reliable advice in those social spheres where individuals closely trust each other (Butler, Grice, \& Reed, 2006). The trusted sources of advice include family, friends, peers, and professional consultants (Coetzer, Battisti, Jurado, \& Massey, 2011).

\subsubsection{Sharing Processes}

Knowledge transfer is an important component of $\mathrm{KM}$ process (Cabrera \& Cabrera, 2002).The findings of the current study suggest that the sharing process of $\mathrm{KM}$ primarily involves the use of a combination of e-mail 
communication, informal meetings, and conversations and mentoring. E-mail is the primary method of external communication with customers and stakeholders in knowledge-intensive small businesses. Advances in technology have led the knowledge-intensive small businesses to replace mail with e-mail.

Common methods of sharing knowledge within knowledge-intensive small businesses are informal in nature (e.g., informal meetings, conversations). Similar to the findings of the study by Wei et al. (2011) who found that SMEs employ informal face-to-face methods of transferring knowledge, small businesses share knowledge across organisation via meetings and conversations. The use of informal methods of knowledge transfer is prevalent in small businesses due to their relatively flat organisational structure.

The findings of the interviews suggest that the extent of knowledge transfer within knowledge-intensive small businesses depends on whether employees are salary-based or commission-based. The findings suggest that employees who are on commission-based employment arrangements in the real estate industry are reluctant to share knowledge because they fear losing commission or incentive. In a commission-based employment situation, employees are more likely to engage in office politics and competition. In a culture that emphasises competition, peers and co-workers are less likely to share knowledge (Mohr et al., 2012).

Another method of sharing knowledge within knowledge-intensive small businesses is mentoring. "Mentoring involves the commitment of time and specific efforts by a more experienced person to the development of a mutually beneficial, supportive and nurturing relationship with a less experienced person" (Moodie \& Fisher, 2009, p. 1). Although mentoring was perceived to be an effective method of sharing knowledge, one participant viewed it as being risky. The risk associated with mentoring was that individuals (i.e., mentees) who leave organisations, take knowledge away with them and this could be costly to organisations. This is where small businesses should consider the importance of HRM and implement policies that assist them in retaining key talents. 


\subsubsection{Storing Processes}

The primary method of storing knowledge is adopting data management software. The findings indicate that an extensive amount of stored knowledge relates to operational activities (e.g., storing new customers' details, telephone conversations, meetings, trainings and seminars). Information technology was seen by most of the participants as an effective method of storing knowledge and it has replaced traditional hard copy filing. However, it is still apparent that an extensive amount of tacit knowledge is stored in the minds of individuals. As discussed in the introduction chapter of this study, tacit knowledge is highly personal and it can be accessed through developing bonds and relationships with individuals. Therefore, it is beyond the capacity of software to record tacit knowledge. To store knowledge, first it has to be translated into the social realms of an organisation where individuals socially interact and share knowledge.

\subsection{Factors Fostering KM}

The factors fostering $\mathrm{KM}$ that participants emphasised during the interviews were culture, strategies and purpose, resources, training and education, technology, and motivational aids. Organisational culture was seen as the most important factor in KM. A transparent organisational culture provides employees with a better sense of direction, and encourages them to share knowledge. Other commentators (Davenport et al., 1998; uit Beijerse, 2000; Wong, 2005; Wong \& Aspinwall, 2005) also contend that culture is an important factor in fostering KM. The key ingredients of a knowledge sharing culture are openness and trust. This was also noted by the participants who believed that staff members all can contribute to a culture that fosters knowledge sharing and one that hoards knowledge. However, the key exemplars of a knowledge sharing culture are the executive team and managers.

The other factor that the participants considered important is strategies and purpose. The reason for its importance was attributed to goal clarity and resource allocation. Most participants considered customer service enhancement through the application of new software. Tapping into current 
technology (e.g., cloud computing) was considered a strategic decision. However, small businesses confront challenges in developing strategies that fit their resources (Edelman, Brush, \& Manolova, 2002).

Resources are seen as important enablers of KM. Providing employees with the necessary tools and resources assists small businesses to be more efficient. Due to resource constraints, small businesses should align their strengths with their strategies (Edelman et al., 2002). Interestingly, one participant considered tapping into networks of professional bodies as making effective use of resources. In other words, resources are not merely what is available inside an organisation, but the bonds and relationships that organisations build with other organisations.

Training and education was perceived as an important aspect of organisational learning. One participant claimed that incentives are provided to individuals who attend workshops and seminars. Most participants claimed that physical attendance of seminars and workshops is no longer a necessity. Currently, there are valuable online resources. In addition, the training needs of an organisation can be met through research and access to professional and government bodies' websites. The internal organisational training activities were primarily on-the-job training and mentoring. No participant had attended or heard of any training relating to $\mathrm{KM}$. This raises a question as to whether there are any KM training programs or seminars offered in Western Australia. Nonetheless, informal training (i.e., on the job training) is a common training method in small businesses (Greenidge, Alleyne, Parris, \& Grant, 2012).

The discussion relating to motivational aids was featured in the forms of financial and non-financial incentives. Participants expressed conflicting views regarding financial and non-financial incentives that promote knowledge sharing. However, a general consensus suggested that non-financial rewards such as recognition, encouragement and acknowledgement play an important role in getting people to share their knowledge across an organisation. 
In contrast to the existing $\mathrm{KM}$ literature, technology was perceived as more important than it has been discussed in the literature. The findings suggest that knowledge-intensive small businesses place great emphasis on technology despite its high associated costs. This is in contrast with the findings of Wei et al. (2011) who found that SMEs are reluctant to invest in technology due to its high costs. A majority of the participants in the sample mentioned the use of technology for carrying out their daily operations. "It is difficult to draw a line between what is called information technology and tools for KM" (Lindvall, Rus, \& Sinha, 2003, p. 138). KM applications provide the users with the ability to acquire, record, share, create and apply knowledge (Coakes, 2006). Lindvall et al. refer to some of the document management systems namely: Microsoft SharePoint, Collaborative Document Management Solution (CDM), Xerox FlowPort, Xerox DocuShare, Documentum 5, and Lotus Discovery Server. Each of the above named data management systems has been upgraded, and the latest products are currently available in the market. Knowledge-intensive small businesses should research the market and use the software that meets their needs and that is affordable.

It is important to note that the use of document management systems and other software can primarily assist organisations in managing explicit knowledge. Technology alone cannot leverage tacit knowledge. However, a knowledge sharing culture can be promoted through the integration of human interaction and technology to foster innovation (Fink \& Ploder, 2009b). The integration of human interaction and technology can collaboratively assist organisations in leveraging knowledge more effectively.

Other factors that foster $\mathrm{KM}$ are management leadership and support, $\mathrm{KM}$ processes and activities, organisational infrastructure, HRM, and measurement. Although participants acknowledged the importance of these factors, they were unable to relate them to their organisations. One potential explanation for this could be that the CSFs that Wong and Aspinwall (2005) have identified overlap in practice. For instance, one participant linked motivational aids to leadership and support. 


\subsection{Concluding Remarks}

The present study validates the findings of Hutchinson and Quintas (2008) who found that SMEs do KM without using the term 'KM'. Introducing KM initiatives such as training sessions on $\mathrm{KM}$ will further assist small businesses in fostering their KM practices. In seeking to explore whether participants or their staff members attended any training seminars on $\mathrm{KM}$, it was noted that no participants had attended any workshops on KM nor had they heard if any training was existent. In order to assist small businesses in gaining more awareness regarding KM practices, it is necessary for Western Australian small business development agencies to introduce KM initiatives. Knowledgeintensive small businesses in particular will potentially be the first to attend KM training programs due to their keen interest and willingness in learning to enhance organisational performance. 


\section{CHAPTER 6: CONLUSIONS AND IMPLICATIONS}

The chapter begins with conclusions about the research questions which relate to the KM processes (i.e., identifying, acquiring, sharing, and storing) and the factors fostering KM. Next, the chapter highlights the implications of the study findings for small businesses and small business development agencies. Thereafter, the limitations associated with the study and the implications of these limitations for future research are outlined. Subsequently, the chapter highlights the contributions that the findings of this study make to $\mathrm{KM}$ practitioners, small business owners/managers and to the small business KM literature. The chapter ends with brief concluding remarks.

\subsection{Conclusions about the Research Questions}

This exploratory qualitative study addressed the questions:

1. How do the selected Western Australian small businesses identify, acquire, share and store knowledge?

2. What effects, if any, does the extent of critical success factors (CSFs) adoption have on the processes of identifying, acquiring, sharing and storing knowledge?

The first question was formulated to explore the KM processes (i.e., identifying, acquiring, sharing, and storing) in small businesses. Overall, the study found that knowledge-intensive small businesses in the sample studied generally had a moderate understanding of KM processes. The internet was identified as the most widely used source of knowledge. This is not surprising given the ease and speed with which business information can be accessed through the internet. Although a high emphasis was placed on technology, nonetheless, organisational culture was considered the key ingredient of an effective KM system.

The types of knowledge, knowledge-intensive small businesses acquire are generally for operational reasons (e.g., updates with developments in legislation). However, a strategic approach towards knowledge acquisition was 
noted to be through establishment of relationships and networks with other organisations. This was discussed in the context of developing social capital. A small number of the interview participants noted that they engaged in networking events with other organisations to develop business relationships. The networking events were perceived as forum for identifying and capitalising on business opportunities for small businesses.

The sharing processes of $\mathrm{KM}$ involved a combination of informal methods (face-to-face meetings and conversations) and e-mail. Due to a low hierarchal structure of small businesses, the use of informal methods of communication is deemed to be effective and efficient. However, e-mail is the primary communication method with customers and suppliers and this is largely due to efficiency and ease of access. Similarly, the primary method of storing knowledge is technology-based (i.e., primarily the use of data management software). The use of data management software has replaced the paper files for storing, and this has increased efficiency and effectiveness in daily operations.

In regard to question two that explored the factors that foster $\mathrm{KM}$, the highest perceived importance was attributed to culture, strategies and purpose, resources, training and education, information technology, and motivational aids. A surprising finding was that a majority of participants did not seem to perceive $\mathrm{HRM}$ as an important factor in fostering $\mathrm{KM}$. It is possible that interview participants considered HRM as a separate department, which is typically non-existent in small business settings. However, it is important to note that HRM is a key facilitator of KM, and KM is largely a people based activity. To ensure organisations gain enhanced performance in KM endeavours, HRM should be considered a central enabler of KM success.

\subsection{Implications for Small Businesses and Development Agencies}

Findings of this study have several important implications for small business owners/managers and KM practitioners. First, knowledge-intensive small businesses have a reasonable $\mathrm{KM}$ awareness and understanding. Small 
businesses in other industries (e.g., manufacturing, construction, retail, etc) can benchmark on the KM strategies of the knowledge-intensive small businesses. Second, knowledge-intensive small businesses place great emphasis on technology. It is important to note that $\mathrm{KM}$ is a human-based activity and; therefore, greater emphasis should be placed on human elements (e.g., retention of key staff) rather than technology.

In order to expand the $\mathrm{KM}$ awareness in the small business community, it is necessary for small business development agencies in Western Australia to take important measures in providing $\mathrm{KM}$ training. The findings of the study suggest that there is a lack of KM training for small businesses. The provision of $\mathrm{KM}$ training has the potential to raise $\mathrm{KM}$ awareness in the small business community and provide basic guidelines for small businesses in their endeavours to employ KM.

\subsection{Limitations and Implications for Future Research}

While findings of this study help develop understanding of $\mathrm{KM}$ in small businesses, it is subject to a number of limitations. First, the sample size was small, but reasonable for an Honours thesis. Second, a majority of participants in the sample were male. A balance of male and female participants could have generated a potentially different set of findings. For instance, there is some evidence that women have somewhat better interpersonal skills than men and this translates into their relatively greater use of the participative leadership style that facilitates knowledge sharing(McShane et al., 2010). Third, all participants in the sample were managers and directors. Including the views of employees in the study would have potentially produced a different perspective on KM. Therefore, generalising the findings of the study should be considered with caution.

There are several avenues to explore in future studies of $\mathrm{KM}$ in the small business context. First, future studies should include employees in the sample. Including employees in future studies has the potential to enhance understanding of $\mathrm{KM}$ as $\mathrm{KM}$ is everyone's contribution rather than views of 
owners/managers alone. Second, a case study method could be employed to validate the findings of the present study and to provide a more holistic understanding of $\mathrm{KM}$ in small businesses. Third, small businesses in other industries (e.g., manufacturing, construction, retail, etc) should be studied to explore their KM practices.

\subsection{Contributions of the Study}

This study has contributed to an understanding of $\mathrm{KM}$ in small businesses by targeting Western Australian knowledge-intensive small businesses. The study findings make a contribution to the small business community, KM practitioners, and to the small business $\mathrm{KM}$ literature. First, it provides a preliminary framework for those small businesses that lack KM awareness. Second, the study provides views of the owners/managers of knowledge-intensive small businesses that are deemed to make better use of knowledge capital. This can form the basis of KM strategy for other small businesses that intend to employ $\mathrm{KM}$. Third, the KM investigation into two topic areas of $\mathrm{KM}$ processes and factors fostering $\mathrm{KM}$ is possibly among the first studies in the Western Australian small business context. Hence, findings of this study can provide practical guidance to those small businesses that need to embrace KM strategy.

\subsection{Concluding Remarks}

The primary objective of this study was to explore how the selected Western Australian knowledge-intensive small businesses identify, acquire, share and store knowledge; and the factors that assist them in the KM processes. Interestingly, the findings reveal that knowledge-intensive small businesses have a moderate KM understanding. Thus, findings of this study can serve as a preliminary framework for those small businesses that lack KM awareness. To gain competitive advantage through $\mathrm{KM}$, the general strategies of small business organisations, including their HR strategy should be aligned with their $\mathrm{KM}$ strategy. Furthermore, it is necessary to include all organisational members 
in KM activities; thus, a high emphasis should be placed on HRM practices that promote a culture that values knowledge sharing. 


\section{REFERENCES}

Abeson, F., \& Taku, M. A. (2006). Knowledge source and small business competitiveness. Competition Forum, 4(2), 464-469.

Adler, P. S., \& Kwon, S. (2002). Social Capital: Prospects for a new concept. The Academy of Management Review, 27(1), 17-40.

Akhavan, P., Jafari, M., \& Fathian, M. (2006). Critical success factors of knowledge management systems: A multi-case analysis European Business Review, 18(2), 97-113.

Alam, S. S. (2009). Adoption of internet in Malaysian SMEs. Journal of Small Business and Enterprise Development, 16(2), 240-255.

Alavi, M., \& Leidner, D. E. (2001). Review: knowledge management and knowledge management systes: conceptual foundations and research issues. MIS Quarterly, 25(1), 107-136.

Amalia, M., \& Nugroho, Y. (2011). An innovation perspective of knowledge management in a multinational subsidiary. Journal of Knowledge Management, 15(1), 71-87.

Australian Bureau of Statistics. (2001). Small business in Australia (Cat. No. 1321.0). Retrieved from http://www.abs.gov.au

Australian Bureau of Statistics. (2007). Research Paper: Explorations of innovation and business performance using linked firm-level data (Cat. No. 1351.0.55.020). Retrieved from http://www.abs.gov.au

Australian Bureau of Statistics. (2010). Characterstics and performance of small and mediumsized businesses in Australia (Cat. No. 1350.0). Retrieved from http://www.abs.gov.au

Baron, A. (2011). Measuring human capital. Strategic HR Review, 10(2), 30-35.

Barrett, R., Mayson, S., \& Warriner, N. (2008). The relationship between small firm growth and HRM practices. In R. Barret \& S. Mayson (Eds.), International handbook of enterpreneurship and HRM. Glos, UK: Edward Elgar Publishing Limited.

Berg, B. L., \& Lune, H. (2012). Qualitative research methods for the social sciences (8th ed.). New Jersey, USA: Pearson Education, Inc.

Bishop, D. (2011). The importance of being an insider: How networks influence the small firm's engagement with formal training. Journal of European Industrial Training, 35(4), 326344.

Boxall, P. (2012). High-peformance work systems: What, why, how and for whom? Asia Pacific Journal of Human Resources, 50, 169-186.

Bozbura, F. T. (2007). Knowledge management practices in Turkish SMEs. Journal of Enterprise Information Management, 20(2), 209-221.

Bryman, A. (2008). Social research methods (3rd ed.). NY, USA: Oxford University Press Inc.

Butler, A., Grice, P. L., \& Reed, M. (2006). Delimiting knowledge transfer from training. Education + Training, 48(8/9), 627-641.

Cabrera, A., \& Cabrera, E. F. (2002). Knowledge-sharing dilemmas. Organization Studies, 23(5), 687-710.

Carlsson, S. A. (2003). Knowledge managing and knowledge management systems in interorganizational networks. Knowledge and Process Management, 10(3), 194-206.

Carlucci, D., \& Schiuma, G. (2006). Knowledge asseets value spiral: linking knowledge assets to company's performance. Knowledge and Process Management, 13(1), 35-46.

Coakes, E. (2006). Storing and sharing knowledge: Supporting the management of knowledge made explicit in transnational organisations. The Learning Organization, 13(6), 579593.

Coetzer, A., Battisti, M., Jurado, T., \& Massey, C. (2011). The reality of management development in SMEs. Journal of Management \& Organization, 17(3), 290-306. 
Coetzer, A., Cameron, A., Lewis, K., Massey, C., \& Harris, C. (2007). Human resource management practices in selected New Zealand small and medium-sized enterprises. International Journal of Organisational Behaviour, 12(1), 17-32.

Darroch, J., \& McNaughton, R. (2002). Examining the link between knowledge management practices and types of innovation. Journal of Intellectual Capital, 3(3), 210-222.

Davenport, T. H., De Long, D. W., \& Beers, M. C. (1998). Successful knowledge management projects. Sloan Management Review, 39(2), 43-57.

Davenport, T. H., \& Volpel, S. C. (2001). The rise of knowledge towards attention management. Journal of Knowledge Management, 5(3), 212-221.

Delgado-Verde, M., Castro, M., \& Navas-Lopez, J. E. (2011). Organizational knowledge assets and innovation capability. Journal of Intellectual Capital, 12(1), 5-19.

Demarest, M. (1997). Understanding knowledge management. Long Range Planning, 30, 374384.

Department for Business Innovation \& Skills. (2010). Statistical Press Release.

Desouza, K. C. (2010). Winning the business case for knowledge management. Business Information Review, 27(3), 159-174.

Desouza, K. C., \& Awazu, Y. (2006). Knowledge management at SMEs: Five peculiarities. Journal of Knowledge Management, 10(1), 32-43.

Earl, M. (2001). Knowledge management strategies: toward a taxonomy. Journal of Management Information Systems, 18(1), 215-233.

Edelman, L. F., Brush, C. G., \& Manolova, T. S. (2002). The impact of human and organizational resources on small firm strategy. Journal of Small Business and Enterprise Development, 9(3), 236-244.

Edvardsson, I. R. (2008). HRM and knowledge management. Employee Relations, 30(5), $553-$ 561.

Fink, K., \& Ploder, C. (2007). A comparative studyof knowledge processes and methods in Austrian and Swiss SMEs. Paper presented at the Proceedings of the $15^{\text {th }}$ European Conference on Information Systems (ECIS2007).

Fink, K., \& Ploder, C. (2009a). Balanced system for knowledge process management in SMEs. Journal of Enterprise Information Management, 22(1/2), 36-50.

Fink, K., \& Ploder, C. (2009b). Knowledge management toolkit for SMEs. International Journal of Knowledge Management, 5(1), 46-60.

Freeze, R. D., \& Kulkarni, D. (2007). Knowledge management capability: defining knowledge assets. Journal of Knowledge Management, 11(6), 94-109.

Frey, R. S. (2001). Knowledge management, proposal development, and small businesses. Journal of Management Development, 20(1), 38-54.

Greenidge, D., Alleyne, P., Parris, B., \& Grant, S. (2012). A comparative study of recruitment and training practices between small and large businesses in an emerging market economy: The case of Barbados. Journal of Small Business and Enterprise Development, 19(1), 164-182.

Greiner, M. E., Bohmann, T., \& Krcmar, H. (2007). A strategy for knowledge management. Journal of Knowledge Management, 11(6), 3-15.

Grover, V., \& Davenport, T. H. (2001). General perspectives on knowledge management: forstering a research agenda. Journal of Management Information Systems, 18(1), 521.

Hagan, F. E. (2006). Research methods in criminal justice and criminalogy. Boston, MA: Allyn and Bacon.

Hakim, C. (2000). Research design: Successful designs for social and economic research (2nd ed.). London, UK: Routledge.

Harkema, S. (2003). A complex adaptive perspective on learning within innovation projects. The Learning Organization, 10(6), 340-346. 
Harris, L., Rae, A., \& Misner, I. (2012). Punching above their weight: The changing role of networking in SMEs. Journal of Small Business and Enterprise Development, 19(2), 335351.

Hislop, D. (2010). Knowledge management as an ephemeral management fashion? Journal of Knowledge Management, 14(6), 779-790.

Hoffman, J. J., Hoelscher, M. L., \& Sherif, K. (2005). Social capital, knowledge management, and sustained superior performance. Journal of Knowledge Management, 9(3), 93100.

Holmes, R., Dahan, H. M., \& Ashari, H. (2006). A guide to research in the social sciences. Selangor: Prentice Hall.

Holste, J. S., \& Fields, D. (2010). Trust and tacit knowledge sharing and use. Journal of Knowledge Management, 14(1), 128-140.

Huber, G. P. (1991). Organizational learning: The contributing processes and the literatures Organizational Science, 2(1), 88-115.

Hutchings, K., De Cieri, H., \& Shea, T. (2011). Employee attraction and retention in the Australian resources sector. Journal of Industrial Relations, 53(1), 83-101.

Hutchinson, V., \& Quintas, P. (2008). Do SMEs do knowledge management? Or simply manage what they know? International Small Business Journal, 26(2), 131-154.

Inkpen, A. C., \& Tsang, E. W. K. (2005). Social capital, networks, and knowledge transfer. Academy of Management Review, 30(1), 146-165.

Ivan, S., \& Eleni, S.-C. (2007). Connecting human resources management and knowledge management. International Journal of Manpower, 28(3/4), 197-206. doi: 10.1108/01437720710755209

Janz, B. D., \& Prasarnphanich, P. (2003). Understanding the antecedents of effective knowledge management: The Importance of a knowledge-centered culture. Decision Sciences, 34(2), 351-384. doi: 10.1111/1540-5915.02328

Jarrar, Y. F. (2002). Knowledge management: learning for organisational experience. managerial Auditing Journal, 17(6), 322-328.

Johnston, S., \& Paladino, A. (2007). Knowledge management and involvement in innovations in MNC subsidiaries. Management International Review, 47, 281-302.

Keen, P., \& Tan, M. (2007). Knowledge fusion: A framework for extending the rigor and relevance of knowledge management. International Journal of Knowledge Management, 3(4), 1-17.

KPMG. (1998). Knowledge Management Research Report.

Lee, M. R., \& Lan, Y. (2011). Toward a unified knowledge management model for SMEs. Expert Systems with Applications 38, 729-735.

Liebowitz, J. (1999). Key ingredients to the success of an organization's knowledge management strategy. Knowledge and Process Management, 6(1), 37-40.

Lindvall, M., Rus, I., \& Sinha, S. S. (2003). Software systems support for knowledge management. Journal of Knowledge Management, 7(5), 137-150. doi: 10.1108/13673270310505449

Liyanage, C., Elhag, T., Ballal, T., \& Li, Q. (2009). Knowledge communication and translation- a knowledge transfer model. Journal of Knowledge Management, 13(3), 118-131.

Lowik, S., Rossum, D. V., Kraaijenbrink, J., \& Groen, A. (2012). Strong ties as sources of new knowledge: How small firms innovate through bridging capabilities. Journal of Small Business Management, 50(2), 239-256.

Marshall, C., \& Rossman, G. B. (1995). Designing qualitative research (2nd ed.). Thousand Oaks, California: Sage Publications, Inc.

Massey, A. P., Ramesh, V., \& Montoya-Wiss, M. M. (2005). Enhancing performance through knowledge management: a holistic framework. International Journal of Knowledge Management, 1(4), 23-42. 
Maylor, H., \& Blackmon, K. (2005). Researching business and management. Hampshire, UK: Palgrave Macmillan.

McShane, S., Olekalns, M., \& Travaglione, T. (2010). Organisational behaviour on the Pacific Rim (3rd ed.). North Ryde, NSW: McGraw-Hill Australia Pty Limited.

Miles, M. B., \& Huberman, A. M. (1994). Qualitative data analysis: An expanded sourcebook (2nd ed.). Thousand Oaks, CA: Sage.

Ministry of Economic Development. (2010). SMEs in New Zealand: Structure and dynamics 2010.

Mohr, D. C., Young, G. J., \& Burgess, J. J. F. (2012). Employee turnover and operational performance: the moderating effect of group-oriented organisational culture. Human Resource Management Journal, 22(2), 216-233. doi: 10.1111/j.17488583.2010.00159.x

Moodie, M. L., \& Fisher, J. (2009). Are youth mentoring programs good value-for-money? An evaluation of the Big Brothers Big Sisters Melbourne Program. BMC Public Health, 9(41), 1-9.

Mu, J., Peng, G., \& Love, E. (2008). Interfirm networks, social capital, and knowledge flow. Journal of Knowledge Management, 12(4), 86-100.

Muhammed, S., Doll, W. J., \& Deng, X. (2009). A model of interrelationships among individual level knowledge management success meassures ${ }^{1}$. International Journal of Knowledge Management, 5(1), 1-16.

Nakra, P. (2000). Knowledge management: the magic is in the culture! Competitive Intelligence Review, 11(2), 53-60.

Nonaka, I., \& Konno, N. (1998). The concept of "Ba": Building a foundation for knowledge creation. California Management Review, 40(3), 40-54.

Oltra, V. (2005). Knowledge management effectiveness: The role of HRM. Journal of Knowledge Management, 9(4), 70-86.

Omerzel, D. G., Antoncic, B., \& Ruzzier, M. (2011). Developing and testing a multi-dimensional knowledge management model on Slovenian SMEs. Baltic Journal of Management, 6(2), 179-204.

Organisation for Economic Co-operation and Development. (2002). OECD small and medium enterprise outlook. Paris.

Organisation for Economic Co-operation and Development. (2005). Oslo Manual: Guidelines for collecting and interpreting innovation data (3rd ed.). Paris.

Palakshappa, N., \& Gordon, M. (2007). Collaborative business relationships: Helping firms to acquire skills and economies to prosper. Journal of Small Business Enterprise and Development, 14(2), 264-279.

Patton, M. Q. (2002). Qualitative research \& evaluation methods (3rd ed.). Thousand Oaks, California: Sage Publications Ltd.

Plessis, M. (2007). The role of knowledge management in innovation. Journal of Knowledge Management, 11(4), 20-29.

Polanyi, M. (1962). Personal knowledge. New York: Harper.

Probst, G., Raub, S., \& Romhardt, K. (2002). Managing knowledge: Building blocks for success. Chichester, UK: Wiley.

Qiu, M., \& Xu, S. (2011). Hypercompetition, customer knowledge, social networks and sustainability. European Journal of Management, 11(4), 138-145.

Qu, S. Q., \& Dumay, J. (2011). The qualitative research interview. Qualitative Research in Accounting \& Management, 8(3), 238-264.

Quintas, P., Lefrere, P., \& Jones, G. (1997). Knowledge management: a strategic agenda. Long Range Planning, 30(3), 385-391.

Salojarvi, S., Furu, P., \& Sveiby, K. E. (2005). Knowledge management and growth in Finnish SMEs. Journal of Knowledge Management, 9(2), 103-122. 
Sandhawalia, B. S., \& Dalcher, D. (2011). Developing knowledge management capabilities: a structured approach. Journal of Knowledge Management, 15(2), 313-328.

Simons, H. (2009). Case study research in practice. London, UK: SAGE Publications Ltd.

Sitlington, H. (2012). Knowledge sharing: Implications for downsizing and restructuring outcomes in Australian organisations. Asia Pacific Journal of Human Resources, 50, 110-127.

Sivaramakrishnan, S., Delbaere, M., Zhang, D., \& Bruning, E. (2010). Critical success factors and outcomes of market knowledge management: Conceptual model and empirical evidence. International Journal of Knowledge Management, 6(3), 1-21.

Small Business Administration. (2010). The small business economy: A report to the president. Washington: United States Government Printing Office.

Stacy, R. (2000). The emergence of knowledge in organizations. Emergence, 2(4), 23-39.

Statistics New Zealand. (2009). Innovation in New Zealand: 2009. Retrieved from http://www.stats.govt.nz

Sutton, D. C. (2001). What is knowledge and can it be managed? European Journal of Information Systems, 10(2), 80-88.

Swanborn, P. (2010). Case study research. London, UK: SAGE Publications Ltd.

Swart, J., Kinnie, N., \& Purcell, J. (2003). People performance in knowledge-intensive firms. London: CIPD.

Theriou, G. N., \& Chatzoghlou, P. D. (2008). Enhancing performance through best HRM practices, organizational learning and knowledge management: A conceptual framework. European Business Review, 20(3), 185-207.

Thite, M. (2004). Strategic positioning of HRM in knowledge-based organizatioins. The Learning Organization, 11(1), 28-44.

Truss, C., Mankin, D., \& Kelliher, C. (2012). Strategic human resource management. New York: Oxford University Press.

uit Beijerse, R. P. (2000). Knowledge management in small and medium-sized companies: Knowledge management for enterpreneurs. Journal of Knowledge Management, 4(2), 162-179.

Vanderstoep, S. W., \& Johnston, D. D. (2009). Research methods for everyday life: Blending qualitative and quantitative approaches. San Francisco, CA: John Wiley \& Sons, Inc.

Vorakulpipat, C., \& Rezgui, Y. (2008). An evolutionary and interpretive perspective to knowledge management. Journal of Knowledge Management, 12(3), 17-34.

Wei, C. C., Choy, C. S., \& Chew, G. G. (2011). The KM processes in Malaysian SMEs: an empirical validation. Knowledge Management Research \& Practice, 9, 185-196.

Wong, K. Y. (2005). Critical success factors for implementing knowledge management in small and medium enterprises. Industrial Management \& Data Systems, 105(3), 261-279.

Wong, K. Y., \& Aspinwall, E. (2004). Characterizing knowledge management in the small business environment. Journal of Knowledge Management, 8(3), 44-61.

Wong, K. Y., \& Aspinwall, E. (2005). An empirical study of the important factors for knowledgemanagement adoption in the SME sector. Journal of Knowledge Management, 9(3), 64-82.

Wright, P. M., \& Snell, S. A. (1991). Toward an integrative view of strategic human resource management. Human Resource Management Review, 1(3), 203-225.

Xu, J., Houssin, R., Caillaud, E., \& Gardoni, M. (2010). Macro process of knowledge management for continuous innovation. Journal of Knowledge Management, 14(4), 573- 591.

Yin, R. K. (2003). Case study research: Design and methods (Third ed.). California: Sage Publications, Inc.

Zhang, J., \& Hamilton, E. (2009). A process model of small business owner-managers' learning in peer networks. Education \& Training, 51(8/9), 607-623. 
Zikmund, W. G., Babin, B. J., Carr, J. C., \& Griffin, M. (2010). Business research methods (8th ed.). Mason, $\mathrm{OH}$ : South-Western Cengage Learning.

Zins, C. (2007). Conceptual approaches for defining data, information and knowledge. Journal of the American Society for Information Science \& Technology, 58(4), 479-493. 


\section{APPENDICES}

\section{Appendix I}

\section{Information Letter}

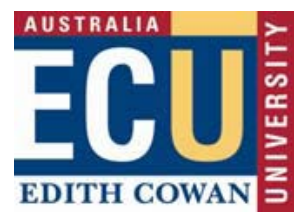

\section{Knowledge Management in Western Australian Small Businesses}

My name is Shukrullah Fassehi. I am currently undertaking an Honours research project at Edith Cowan University under the supervision of Dr Alan Coetzer and Dr Pattanee Susomrith.

My study seeks to answer fundamental questions such as: (1) How do small businesses identify, acquire, share and store knowledge? (2) What factors affect the processes of identifying, acquiring, sharing and storing knowledge? Findings of the study may hold important lessons for knowledge intensive small businesses that are seeking to improve their knowledge management endeavours. Therefore, your insights will be invaluable to my study.

Participation in this research requires you to take part in a face-to-face interview. Your opinions are extremely worthwhile so please understand that there are no wrong or right answers to the interview questions. The questions should take approximately 45 minutes to answer.

Your participation in this research is completely voluntary. You are free to withdraw at anytime. If at any stage you feel uncomfortable about the questions that I ask during the interview then please let me know and we can move onto the next question (s) or finish the interview if that is what you wish.

With your consent the interview will be recorded to ensure accuracy of the interview data. I will inform you when the recorder is being turned on or off. If you wish, I will provide you with a copy of the transcript and you are welcome to edit the transcript if necessary. Please be assured that all information collected from this interview will remain strictly confidential, and participants and business names will not be revealed. The data from this study will be used to write conference and journal papers. It may 
also be used in future research for a higher level academic qualification. When writing for publication, no identifying information will be used.

This research has been approved by the Faculty of Business and Law Ethics Committee. If you have any questions or would like to get further information about this study, please do not hesitate to contact me. If you wish to speak with someone not connected with the study, please contact:

Human Research Ethics Officer

Edith Cowan University

270 Joondalup Drive

Joondalup WA 6027

Phone: +61 863042170

Email: research.ethics@ecu.edu.au

Researcher

Shukrullah Fassehi

Honours Student

School of Management

Faculty of Business and Law

Edith Cowan University

Telephone:

Email: sfassehi@our.ecu.edu.au

Research Supervisor

Dr Alan Coetzer

Senior Lecturer

School of Management

Faculty of Business and Law

Edith Cowan University

Telephone: 63042202

Email: a.coezter@ecu.edu.au

Research Co-supervisor

Dr Pattanee Susomrith

Lecturer

School of Management

Faculty of Business and Law

Edith Cowan University

Telephone: 63042129

Email: p.susomrith@ecu.edu.au 


\section{Appendix II}

\section{Project Title:}

\section{Knowledge Management in Western Australian Small Businesses}

\section{Consent Form}

I understand the aims of the project, the benefits and potential risks and that my participation is completely voluntary. I realise that I can withdraw at any time and that I am not obligated to answer questions. I understand that any information I provide will remain confidential, my identity and business name will not be revealed and the collected data will not be used for purposes other than this research project. I understand that data from this study will be used to write conference and journal papers, and that it may also be used in future research for a higher level academic qualification. When writing for publication, no identifying information will be used.

I consent to having my interview digitally recorded and transcribed by an independent person who will be required to sign a confidentiality agreement.

Name:

Phone:

Signature:

Date:

Researcher

Shukrullah Fassehi

Honours Student

School of Management

Faculty of Business and Law

Edith Cowan University

Mobile: 0428261116

E-mail: sfassehi@our.ecu.edu.au

Research Supervisor

Dr Alan Coetzer

Senior Lecturer

School of Management

Faculty of Business and Law

Edith Cowan University

Telephone: 63042202

E-mail: a.coezter@ecu.edu.au
Research Co-supervisor

Dr Pattanee Susomrith

Lecturer

School of Management

Faculty of Business and Law

Edith Cowan University

Telephone: 63042129

E-mail: p.susomrith@ecu.edu.au 


\section{Appendix III}

\begin{tabular}{|l|}
\multicolumn{1}{c|}{$\begin{array}{c}\text { Demographic Summary Sheet } \\
\text { Knowledge Management in Western Australian Small Businesses }\end{array}$} \\
\hline Name of interviewee: \\
\hline Position in the organisation: \\
\hline What is your highest level of education? High School/TAFE/University \\
\hline What products or services does your organisation provide? \\
\hline How long have you worked in this industry? \\
\hline Approximately how many employees do you have? \\
\hline How often do you have meetings in your organisation? \\
\hline Do you have a written policy on knowledge management? \\
\hline $\begin{array}{l}\text { How many structured knowledge management training programs have you or your } \\
\text { staff participated in during the past year? }\end{array}$ \\
\hline $\begin{array}{l}\text { Have you used/purchased any software in the past year that could assist you in } \\
\text { carrying on knowledge management practices? }\end{array}$ \\
\hline
\end{tabular}




\section{Appendix IV}

\section{Research Questions}

RQ 1: To determine how small businesses identify, acquire, share and store knowledge?

Question 1:

1. What are the key sources of knowledge and information that you draw on to operate your business?

- What are the key sources of knowledge and information regarding products/services, customers, suppliers and competitors in your organisation?

[Probes: Friends, websites, business partners, employees?

Question 2:

2. What are examples of the knowledge and information that you get from outside your organisation?

— How do you get information in your organisation?

[Probes: getting information through relationships with customers? Suppliers? Competitors?

Question 3:

3. How do you share information in your organisation?

— How do you communicate or transfer information in your organisation?

[Probes: Share information with employees, customers, suppliers, competitors through email, website, face-to-face meetings, conversations?

Question 4:

4. How do you store knowledge in your organisation? 
[Probes: protect information? Documents? Organisational experiences?

— Store in your head, document it on files, save on computer?

RQ 2: To determine factors that assist small businesses in identifying, acquiring, sharing and storing knowledge.

Question 1:

i. Are there any factors that can assist you in carrying out $\mathrm{KM}$ practices? Please tell me about these factors and how they assist in carrying out KM practices.

[Probes: Leadership skills? Culture? Training? Technology?

I have read the literature regarding $\mathrm{KM}$ in small businesses, and have found that there are a few important factors known as critical success factors (CSFs) that assist small businesses in carrying on KM practices. For your information, I will explain a few of them and will ask your views at the end.

Table 1 Wong and Aspinwall's CSFs

. Management leadership and support

. Culture

. Strategies and purpose

. Resources

. Processes and activities

. Training and education

. Human resource management

. Information technology

. Motivational aids

. Organisational infrastructure

. Measurement

ii. What effects, if any, does the extent of CSFs adoption have on the processes of identifying, acquiring, sharing and storing knowledge?

[Probes: More efficient, effective, convenient?

- How do the CSFs assist organisations in looking for the sources of information?

- How do the CSFs assist organisations in getting information?

- How do the CSFs assist organisations in sharing information?

- How do the CSFs assist organisations in storing/protecting information? 